\title{
Hnrnpab regulates neural cell motility through transcription of Eps8
}

\author{
ALEXA A. LAMPASONA ${ }^{1,2}$ and KEVIN CZAPLINSKI $1^{2,3}$ \\ ${ }^{1}$ Program in Molecular and Cellular Pharmacology, Stony Brook University, Stony Brook, New York 11749, USA \\ ${ }^{2}$ Centers for Molecular Medicine, Stony Brook University, Stony Brook, New York 11749, USA \\ ${ }^{3}$ Department of Anesthesiology, Stony Brook University, Stony Brook, New York 11749, USA
}

\begin{abstract}
Cell migration requires a complicated network of structural and regulatory proteins. Changes in cellular motility can impact migration as a result of cell-type or developmental stage regulated expression of critical motility genes. Hnrnpab is a conserved RNA-binding protein found as two isoforms produced by alternative splicing. Its expression is enriched in the subventricular zone (SVZ) and the rostral migratory stream within the brain, suggesting possible support of the migration of neural progenitor cells in this region. Here we show that the migration of cells from the SVZ of developing Hnrnpab ${ }^{-/-}$ mouse brains is impaired. An RNA-seq analysis to identify Hnrnpab-dependent cell motility genes led us to Eps8, and in agreement with the change in cell motility, we show that Eps8 is decreased in Hnrnpab ${ }^{-1-}$ SVZ tissue. We scrutinized the motility of $\mathrm{Hnrnpab}^{-1-}$ cells and confirmed that the decreases in both cell motility and Eps 8 are restored by ectopically coexpressing both alternatively spliced Hnrnpab isoforms, therefore these variants are surprisingly nonredundant for cell motility. Our results support a model where both Hnrnpab isoforms work in concert to regulate Eps 8 transcription in the mouse SVZ to promote the normal migration of neural cells during CNS development.
\end{abstract}

Keywords: RNA binding protein; cell motility; regulation of gene expression

\section{INTRODUCTION}

Genome-wide studies of RNA-binding proteins (RBPs) have revealed the presence of thousands of proteins in the cell that bind to RNAs, many of which were never before predicted due to the lack of structural domains known for RNA-protein interaction (Baltz et al. 2012; Castello et al. 2012). These interactions can function in specific gene regulation pathways, therefore the number of possible RNAbased regulatory events is enormous. Some families of RBPs are widespread throughout evolution, and there are many individual RBPs that are highly conserved, suggesting they may each play unique roles in cellular function (Gerstberger et al. 2014). Significant advances have been made in being able to take a genome-wide picture of the RNAs that an RBP can interact with in cells, but RNA binding to a cognate sequence within an mRNA does not always reflect a functional regulation of an RNA target (MazanMamczarz et al. 2009; Wang et al. 2015). Only through focused study of an individual RBP's function in vivo can we understand the role that it plays in biology.

We have been studying the cellular function of the conserved RNA-binding protein Hnrnpab. Hnrnpab contains

Corresponding author: Kevin.Czaplinski@stonybrook.edu

Article is online at http://www.rnajournal.org/cgi/doi/10.1261/rna. 067413.118. two tandem RNA recognition motif (RRM) domains, an arrangement that is found in many heterogeneous nuclear ribonucleic acid ( $h n R N A$ ) binding proteins (hnRNPs), as well as conserved $\mathrm{N}$-terminal and $\mathrm{C}$-terminal domains (Akindahunsi et al. 2005; Czaplinski et al. 2005; Kroll et al. 2009). Hnrnpab and its orthologs in other organisms have been linked to the cytoplasmic localization or trafficking of mRNAs, suggesting a conserved cellular role for this protein in how subsets of mRNA localize in the cytoplasm (Czaplinski et al. 2005; Czaplinski and Mattaj 2006; Raju et al. 2008, 2011; Kroll et al. 2009). In many organisms, including mammals, Hnrnpab is alternatively spliced, and we have shown that the full-length isoform, Hnrnpab1, is sufficient for the role of this gene in trafficking of $\beta$-actin mRNA in mouse cells (J Sinnamon, AA Lampasona, CA Waddell, K Czaplinski, in prep.). The active localization of $m R N A s$ for the actin regulatory machinery has been shown to have a profound impact on cytoskeleton function such as cell motility, so we considered that Hnrnpab may have a role in cell motility (Kislauskis et al. 1997; Shestakova et al. 2001;

(C) 2019 Lampasona and Czaplinski This article is distributed exclusively by the RNA Society for the first 12 months after the full-issue publication date (see http://rnajournal.cshlp.org/site/misc/terms.xhtml). After 12 months, it is available under a Creative Commons License (Attribution-NonCommercial 4.0 International), as described at http:// creativecommons.org/licenses/by-nc/4.0/. 
Condeelis and Singer 2005; Dormoy-Raclet et al. 2007; Bunnell et al. 2011; Katz et al. 2012; Liao et al. 2015). There is evidence that Hnrnpab can impact cell motility in hepatocarcinoma cell lines, where either overexpression or knockdown was able to impair motility of different lines (Zhou et al. 2014).

We have previously shown that in neurosphere cultures initiated from $\mathrm{Hnrnpab}^{-/}$newborn mouse brains many fewer nestin-expressing progenitor cells are found than in Hnrnpab ${ }^{+/-}$controls, suggesting Hnrnpab functions within this population of neural progenitor cells (NPCs). Hnrnpab ${ }^{-/-}$neurons are also hypersensitive to glutamate stimulated excito-toxicity (Sinnamon et al. 2012). A function for Hnrnpab in the developing nervous system is also indicated by the high expression of Hnrnpab early in the mouse CNS (McKee et al. 2005; Lein et al. 2007). A similar developmental pattern is also observed in Xenopus laevis, where perturbing Hnrnpab function leads to anterior developmental defects; perturbation of the Hnrnpab ortholog, 40LoVe/Samba results in cell autonomous migration defects of neural crest derived cells, increased apoptosis, and anterior morphology defects (Dichmann et al. 2008; Yan et al. 2009). Although it is clear that Hnrnpab is involved in nervous system development, the molecular function for Hnrnpab has not been identified.

Within the brain, one region where Hnrnpab is enriched is the SVZ and the adjacent rostral migratory stream (RMS) from the SVZ to the olfactory bulb (OB). Neural progenitor cells (NPCs) reside in the SVZ, from where they proliferate and migrate to promote neurogenesis in the $O B$, gliogenesis, or response to injury (Dizon et al. 2006; GonzalezPerez and Alvarez-Buylla 2011; Lim and Alvarez-Buylla 2016; Kaneko et al. 2017). A role for Hnrnpab in SVZ cell migration during neural development would be consistent with the pattern of Hnrnpab expression, so we performed experiments to establish this. We report here a decrease in cell motility of cells from SVZ brain tissue of Hnrnpab knockout mice and establish a culture model to dissect this defect at the molecular level. Through RNA-seq analysis and candidate evaluation we determine that the cell motility phenotype results from Hnrnpab-dependent transcription of the Eps8 gene, an actin-binding Rac-GEF factor. Unexpectedly, coexpression of both isoforms of Hnrnpab are required to restore motility and Eps8 expression. This study reveals a specific molecular function for Hnrnpab in SVZ cell motility and uncovers the molecular target behind it.

\section{RESULTS}

\section{Cell motility is decreased in the subventricular zone (SVZ) of Hnrnpab ${ }^{-1-}$ mice}

Hnrnpab mRNA is highly expressed in the central nervous system during early development and has been shown to regulate development and neuron survival (Gong et al. 2003; McKee et al. 2005; Sinnamon et al. 2012). In postnatal rodents, Hnrnpab expression in the CNS is not uniform; Hnrnpab mRNA is enriched in the SVZ, RMS, OB, the granule layers of the hippocampus $(\mathrm{HC})$, and the cerebellum (Rushlow et al. 1999; Gong et al. 2003; Lein et al. 2007). The SVZ contains NPC s that proliferate and migrate through the RMS to the OB to support neurogenesis throughout life (Ming and Song 2011; Lim and Alvarez-Buylla 2016; Apostolopoulou et al. 2017). High Hnrnpab mRNA expression in the SVZ through the RMS and OB is consistent with a role in NPC migration. We plated tissue explants prepared from the SVZ of Hnrnpab ${ }^{+/-}$and Hnrnpab ${ }^{-/-}$mice and cultured these for $48 \mathrm{~h}$ prior to imaging. We analyzed the distance that cells had migrated from each explant and we quantified the area occupied by the migrating cells minus the area of the explant itself (Fig. 1A). There was a $37 \%$ reduction in the average migration area of $\mathrm{Hnrnpab}^{-/-}$ SVZ explants $\left(3.55 \times 10^{5} \mu \mathrm{m}^{2}\right.$, Fig. 1B) as compared to Hnrnpab ${ }^{+/-}$tissue $\left(5.56 \times 10^{5} \mu^{2}\right.$, Fig. 1B). We also quantified the average distance from the edge of the explant to the leading edge of cells migrating away from the explant; cells from Hnrnpab ${ }^{-/-}$SVZ explants (167.3, Fig. 1C) migrated $31 \%$ less than cells from $\mathrm{Hnrnpab}^{+/-}$explants $(240.5 \mu \mathrm{m}$, Fig. 1C). Changes in the cell motility machinery are most likely to explain these decreases in migration area, although changes in proliferation or cell death could also contribute. We used time-lapsed imaging of $\mathrm{Hnrnpab}^{-/-}$cells in culture to examine the role of Hnrnpab in cell motility.

\section{Hnrnpab1 and Hnrnpab2 promote cell motility through the RRMs}

To facilitate analysis of cell motility, we immortalized cells from newborn mouse cerebral cortex from $\mathrm{Hnrnpab}^{+/+}$and $\mathrm{Hnrnpab}^{-/-}$littermates (immortalized neural cells, INCs). Using these INCs we performed monolayer-scratch assays and measured the velocity of individual cells moving into the wound. We found that Hnrnpab ${ }^{-/-}$INCs have a significantly decreased average cellular velocity compared to Hnrnpab ${ }^{+/+}$INCs. (Fig. 2A, Hnrnpab ${ }^{+/+}$: $0.600 \mu \mathrm{m} / \mathrm{min}$, Hnrnpab $\left.{ }^{-/}: 0.354 \mu \mathrm{m} / \mathrm{min}\right)$. To ask if Hnrnpab was able to correct this cell motility deficit, we created recombinant lentivirus particles expressing Hnrnpab1 to stably express Hnrnpab1 in Hnrnpab-/- INCs (Hnrnpab1 on Fig. 2A). However, these cells move with an average velocity of $0.405 \mu \mathrm{m} / \mathrm{min}$, which is not significantly higher than $\mathrm{Hnrnpab}^{-/-}$(Fig. 2A). We investigated whether the other isoform, Hnrnpab2, stably expressed in the same manner as Hnrnpab1 in Hnrnpab-/- INCs could rescue motility (Hnrnpab2 on Fig. 2A), and found that this too was unable to rescue the velocity (average velocity of $0.324 \mu \mathrm{m} / \mathrm{min}$ ). We then questioned whether it was both isoforms together that were required for proper cell motility. To stably express both Hnrnpab1 and Hnrnpab2 we created 
A

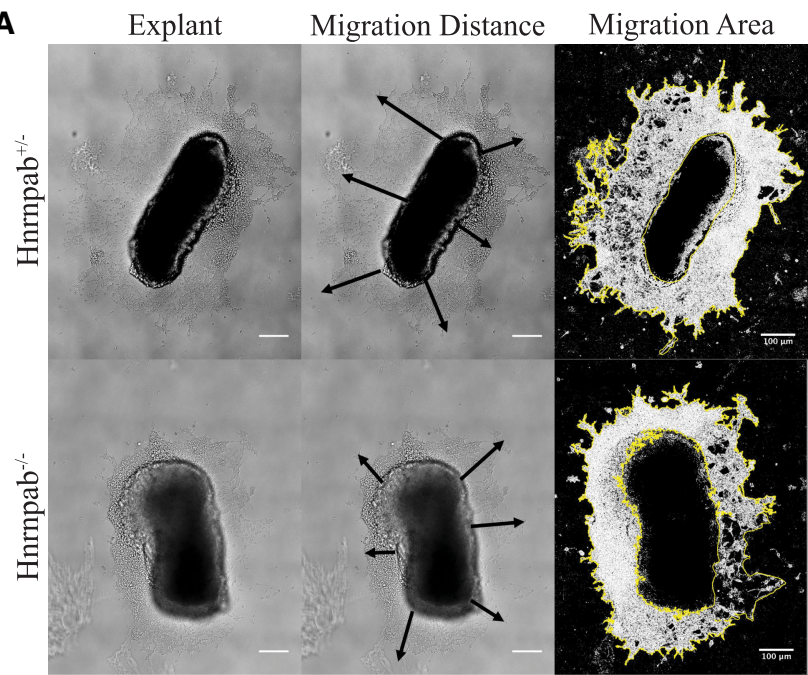

B

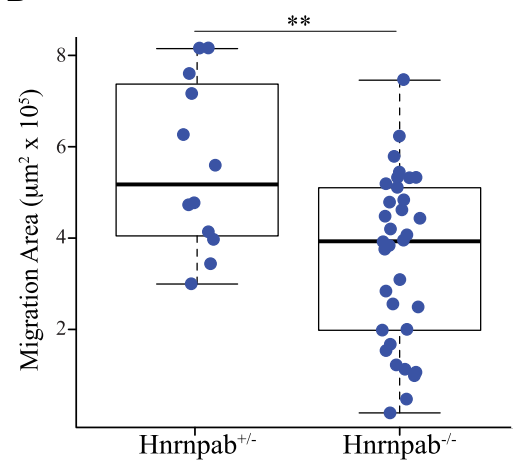

C

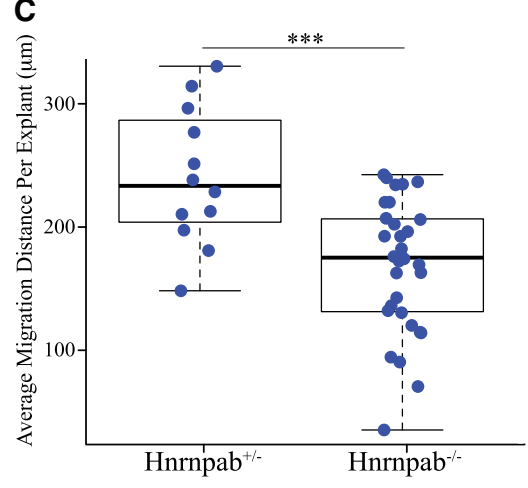

FIGURE 1. Cell migration from SVZ explants is impaired in the absence of Hnrnpab. (A) Representative DIC images of SVZ explants (left panels), with these images indicating the measurement of either migration distance (center panel), or migration area (right panels). (Top panels) Hnrnpab ${ }^{+/-}$; (bottom panels) $\mathrm{Hnrnpab}^{-/-}$. (B) Box and whisker plots of the average migration area measurements (left chart) and migration distance (right chart, each data point represents the average of six measurements around one explant). Hnrnpab ${ }^{+/} n=12$; Hnrnpab ${ }^{-1-} n=29$. $P$-values were calculated using one-way ANOVA followed by a pairwise t-test with Bonferroni correction. $\left(^{* *}\right) P<0.001,\left({ }^{* *}\right) P<0.01$.

recombinant lentivirus particles to express an Hnrnpab mini gene cassette that includes cDNA from exons 1-4 of the open reading frame and genomic DNA from exons 5-8 (Hnrnpab minigene, WT-MG, Fig. 2B). Exon7 in this WT-MG was alternatively spliced in virus-infected cells to give rise to both Hnrnpab1 and Hnrnpab2 at comparable levels to Hnrnpab ${ }^{+/+}$(Fig. 2C,D). Hnrnpab ${ }^{-/-}$INCs expressing this WT-MG moved with an average velocity of $0.591 \mu \mathrm{m} / \mathrm{min}$, which is not significantly different from the average velocity of Hnrnpab ${ }^{+/+}$INCs, therefore both isoforms of Hnrnpab are required for Hnrnpab to function in cell motility (WT-MG in Fig. 2A).

To determine whether Hnrnpab regulates cellular motility through binding its conserved RRMs, we expressed an Hnrnpab MG construct in which two phenylalanines in the RNP1 motifs of each of the RRMs are mutated to valine (Hnrnpab mutant minigene, mut-MG, Fig. 2B). These two phenylalanines provide important interactions between the RNP1 motif and nucleic acid targets for homologous RRM proteins; and these substitutions have been shown to impair base-specific recognition in other RNA-binding proteins (Ding et al. 1999; Enokizono et al. 2005; PérezCañadillas 2006; Cléry et al. 2008). Expressing mut-MG in Hnrnpab ${ }^{-1-}$ INCs does not recover motility, moving with a cellular velocity of 0.429 $\mu \mathrm{m} / \mathrm{min}$ (Fig. 2A). These data suggest Hnrnpab can regulate cell motility through its nucleic acid binding activity and that both Hnrnpab isoforms are needed to regulate INC cell motility.

\section{Hnrnpab regulates the expression of Eps8}

We hypothesized that changes in levels of at least one Hnrnpab target RNA in Hnrnpab ${ }^{-/}$INCs explained the observation of decreased cellular velocity in the cells. We sent RNA from Hnrnpab ${ }^{+/+}$and Hnrnpab ${ }^{-/-}$ INCs for RNA-seq (Supplemental Table SI). Of 76 genes that passed our criteria for at least a twofold change in gene expression, we selected the eight genes that have annotated functions in cell motility that are well defined in the literature. We then screened these eight genes using reverse transcription followed by quantitative real-time PCR (RT-QPCR) for confirmation that selected genes agreed with the RNAseq. There was a change in three of these genes that were consistent with RNA-seq results and therefore might account for the decrease in cell motility (Supplemental Table SII). We further screened their RNA levels for recovery following reexpression of WT-MG but not mut-MG. The RNA levels of only one gene, Eps8 (EGF receptor pathway substrate 8), fit this profile, correlating Eps8 expression with the cell motility phenotype (Supplemental Table SII). RT-QPCR revealed 53-fold lower Eps8 mRNA in Hnrnpab ${ }^{-/}$INCs than Hnrnpab ${ }^{+/+}$and after reexpressing WT-MG in Hnrnpab ${ }^{-1-}$ INCs (Fig. 3A). Eps8 mRNA was mostly restored to only 1.4 -fold lower than Hnrnpab $^{+/+}$, while the mut-MG was unable to restore Eps8 mRNA levels, which remained 40-fold lower after reexpressing mut-MG, not significantly different than Hnrnpab ${ }^{-/-}$INCs alone (Fig. 3A). 
A
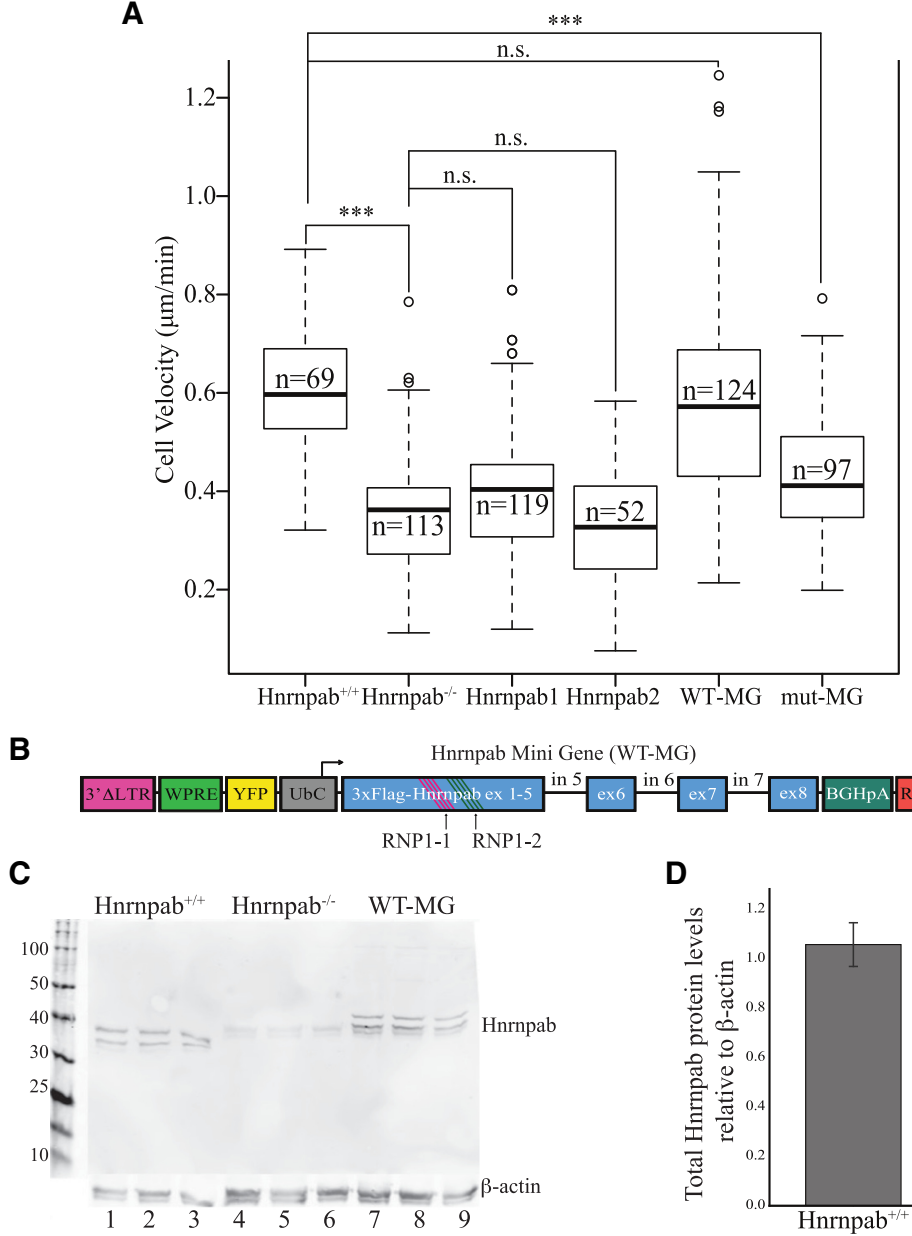

FIGURE 2. Hnrnpab1 and Hnrnpab2 promote INC cell motility through the RRMs. (A) INC monolayers were scratched and imaged live as they filled in the wound. The velocity of cells was measured from these images and the results presented in box and whisker plots. The leftmost experiments were in Hnrnpab ${ }^{+/+}$INCs, while all the other experiments were performed in $\mathrm{Hnrnpab}^{-/-}$INCs, with the reexpression of Hnrnpab isoforms as indicated below. P-values were calculated by one-way ANOVA followed by pairwise t-test with Bonferroni correction. $\left({ }^{* * *}\right) P<0.001$. (B) Diagram of lentiviral vector cassette to reexpress Hnrnpab minigene (WTMG) and Hnrnpab mutant minigene (mut-MG). The first four exons of Hnrnpab cDNA were joined to exons 5-8 of Hnrnpab genomic DNA to facilitate alternative splicing of the recombinant protein cassette. The Hnrnpab MG lies in the inverse orientation of the lentiviral 5' LTR promoter to retain Hnrnpab introns in the proviral genome. Two conserved phenylalanines in the RNP1 motifs of RRM1 (RNP1-1) and RRM2 (RNP1-2) were mutated to valine to create mut-MG. (C) Western blot showing expression of both Hnrnpab isoforms from WT-MG. Protein extracted from three independent cultures were run in parallel from either WT INCs (lanes 1-3), Hnrnpab ${ }^{-1-}$ INCs (lanes 4-6), or Hnrnpab ${ }^{-/-}$INCs stably expressing WT-MG. Blots were probed with an antibody against endogenous Hnrnpab. The molecular weights of Hnrnpab1 and Hnrnpab2 from WT-MG are slightly higher than endogenous Hnrnpab1 and Hnrnpab2 due to 3xFlag tag. (D) The blots from panel $C$ were quantified using Actb as a loading control, and the relative signal of Hnrnpab from WT INCs (gray bar) and $\mathrm{Hnrnpab}^{-/-}$INCs with WT-MG after Hnrnpab ${ }^{-/-}$background subtraction are shown. Error bars represent standard error.

Having identified Eps8 mRNA as a single Hnrnpabdependent motility gene in INCs, we hypothesized that this may reflect regulation of Eps8 mRNA levels in NPCs in the brain to promote migration and neurogenesis. We therefore measured Eps8 mRNA levels from SVZ tissue and found it was decreased in $\mathrm{Hnrnpab}^{-/-}$mice compared to Hnrnpab $^{+/-}$mice (Fig. 3B). There was also a decrease that is less robust in the hippocampus, and is not detected in the liver and lungs, suggesting that regulation of Eps8 is not universal, but is tissue specific, perhaps even cell-type specific within the SVZ and hippocampus (Fig. 3B).

Mice express two major Eps8 protein isoforms, Eps8p97 and Eps8p68, likely produced from a long ( $p 97$ ) and short (p68) promoter (Fig. 4A). Our Eps8 OPCR amplicon captures the mRNA for both of these isoforms, and we observed a concomitant decrease in both Eps8 protein isoforms in Hnrnpab ${ }^{-/-}$INCs compared to Hnrnpab ${ }^{+/+}$INCs (Fig. 4A, compare lanes 1 and 2). Consistent with the mRNA levels, Eps8 protein was restored following expression of WTMG (Fig. 4A, compare lanes 2 and 3). Interestingly, the Eps8p97 isoform was restored to near wild-type levels, while Eps8p68 only weakly recovered (Fig. 4B,C). We confirmed that expression of the individual Eps8p68 and Eps8p97 mRNA transcripts are consistent with the protein levels using Eps8p68 and Eps8p97 mRNA transcript specific amplicons (Supplemental Fig. S1A). These data show Hnrnpab having a greater effect on the expression of the Eps8p97 isoform, and strictly correlate the expression of Hnrnpab with Eps8p97 and INC cell motility. In light of a lack of correlation with any other candidate gene from the RNA-seq data, this strongly implicates Eps8 as a single target gene that accounts for Hnrnpab's role in cell motility.

\section{Exogenous expression of Eps8 in Hnrnpab ${ }^{-/-}$INCs rescues cell motility}

Eps8 regulates actin cytoskeleton reorganization through Rac-GEF activity as well as direct actin capping and bundling activities (Scita et al. 1999, 2001; Disanza et al. 2004, 2006; Hertzog et al. 2010; Vaggi et al. 2011). Eps 8 is part of a trimeric complex that, together with Sos-1 and Abi-1, acts as a Rac-GEF, facilitating Rac-GTP 
A

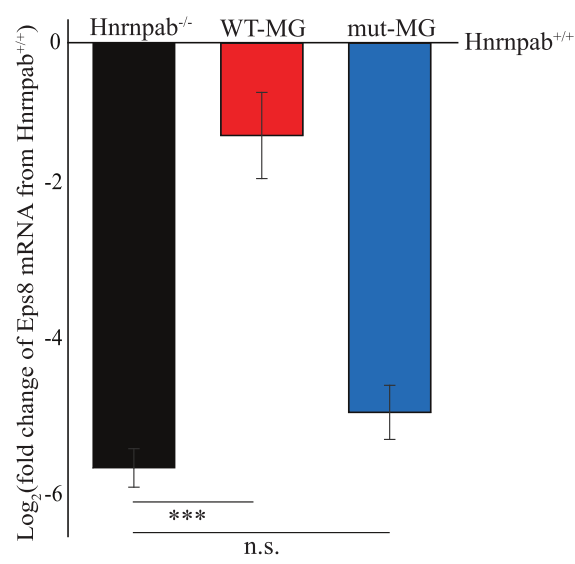

B

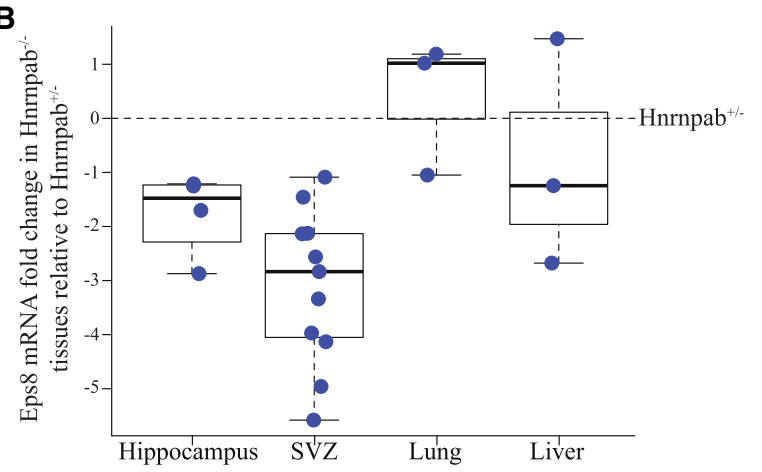

FIGURE 3. Eps8 mRNA level is dependent on Hnrnpab. (A) We quantified Eps8 mRNA levels using RT-QPCR in Hnrnpab ${ }^{+/+}$INCs, $H_{n r n p a b}{ }^{-1}$ INCs, or Hnrnpab ${ }^{-/-}$INCs stably expressing WT-MG or mut-MG INCs as indicated. The results are expressed as the $\log _{2}$ of the fold change relative to Eps8 mRNA in Hnrnpab ${ }^{+/+}$INCs. The data represent measurements from several independent cultures, with each measurement performed in duplicate. Hnrnpab ${ }^{+/+} n=12$; Hnrnpab ${ }^{-1-} n=12$; WT-MG $n=8$; mut-MG $n=8$. P-value analyzed with one-way ANOVA followed by a pairwise t-test with Bonferroni correction. Error bars represent standard error. ( $\left.{ }^{* * *}\right) P<0.001$. (B) Eps8 mRNA is decreased in mouse tissue. Eps8 mRNA in $\mathrm{Hnrnpab}^{+/-}$and Hnrnpab ${ }^{-/-}$littermates was quantified and expressed as a fold change in $\mathrm{Hnrnpab}^{-/-}$relative to Hnrnpab ${ }^{+/-}$. Each data point represents a measurement in duplicate from the indicated tissue of one animal. Dotted line represents no change from Hnrnpab ${ }^{+-}$Esp8 mRNA abundance.

binding and activation (Innocenti et al. 2003). Rac-GTP is a well characterized regulator of actin cytoskeleton polymerization, and is a crucial factor in cell motility as well as several cell contact regulated signaling pathways (Burridge and Wennerberg 2004; Ridley 2006; Murali and Rajalingam 2014). Additionally, Eps8 caps actin filaments when associated with Abi-1 alone, and displays direct actin bundling activity when in complex with BAIAP2/Irsp53 (Funato et al. 2004). Eps8 has also been demonstrated to play a role in endocytic trafficking of EGFR family members, potentially through Rab GTPase activity (Lanzetti et al. 2000; Auciello et al. 2013). All of these processes can significantly impact cell motility dynamics, consistent with our hypothesis that $E p s 8$ is a single gene whose regulation can control cell motility. We reasoned that if lack of Eps8 expression was the cause of the cell motility deficit, then reexpression of Eps8 in Hnrnpab ${ }^{-/-}$cells would rescue cell motility.

To express Eps8 in Hnrnpab ${ }^{-/}$INCs, we cloned Eps8p97 downstream from an internal ribosomal entry site (IRES) to express Eps8p97 protein through cap independent translation (Fig. 5A-C). IRES initiated translation in lentiviral vectors produces significantly less protein compared to cap-dependent translation, and this vector produces Eps8p97 at levels equal to Hnrnpab ${ }^{+/+}$INCs. (Mizuguchi et al. 2000). The average cell velocity of Hnrnpab $^{-/}$INCs expressing Eps8p97 (0.554 $\left.\mu \mathrm{m} / \mathrm{min}\right)$ was not significantly different from that of Hnrnpab ${ }^{+/+}$ INCs, demonstrating that Eps8p97 was sufficient to restore the motility defect of Hnrnpab ${ }^{-/-}$INCs (Fig. 5D). This was not due to a nonspecific stimulation of cell motility, since expression of Eps8p97 in Hnrnpab ${ }^{+/+}$INCs did not affect their average velocity $(0.631 \mu \mathrm{m} / \mathrm{min}$, Fig. 5D). Curiously, Eps8p68 protein levels were also raised after reexpression of Eps8p97, but to only a fraction of the levels measured in Hnrnpab ${ }^{+/+}$INCs, which was also what we observed when expressing the WT-MG (Fig. 5C, compared to Fig. 4A). We performed Eps8p68 specific QPCR and measured a slight increase in the Eps8p68 mRNA transcript levels in either Hnrnpab ${ }^{-/-}$INCs expressing V5-Eps8p97 similar to what we observed in Hnrnpab ${ }^{-1}$ INCs expressing WT-MG (Supplemental Fig. S1B). Based on these observations we suggest that reexpression of Eps8p97 feeds back to weakly increase expression of endogenous Eps8p68, explaining this modest increase in Eps8p68 expression upon reexpression of Hnrnpab. In summary, these results show that the decrease in Eps8 expression in Hnrnpab ${ }^{-1}$ INC cells is sufficient to explain the significantly reduced cellular velocity observed in Hnrnpab-/- INC cells.

\section{Hnrnpab regulates Eps8 transcription}

A decrease in Eps8 RNA level in Hnrnpab ${ }^{-/-}$INCs results from either a change in its transcription or stability, or a combination of these. To determine how Hnrnpab is regulating Eps8 we first evaluated transcription using RT-QPCR with primers designed to amplify the intron-containing pre-mRNA. We measured from the beginning of the Eps8 pre-mRNA transcript using primers that specifically amplified a region within intron 2 and in parallel we also measured the expression with primers targeted to introns 20 and 21 (Fig. 6A). We observed a decrease in Eps8 pre-mRNA levels at both intron 2 and intron 20/21 that was similar in magnitude to that of the Eps8 mRNA, suggesting that it is transcription of Eps8 RNA that is altered in Hnrnpab-/- INCs. This change in Eps8 premRNA levels was rescued by the WT-MG but is not rescued by the mut-MG (Fig. 6B). We measured the half-life of Eps8 mRNA after transcription inhibition with ActD, 
A

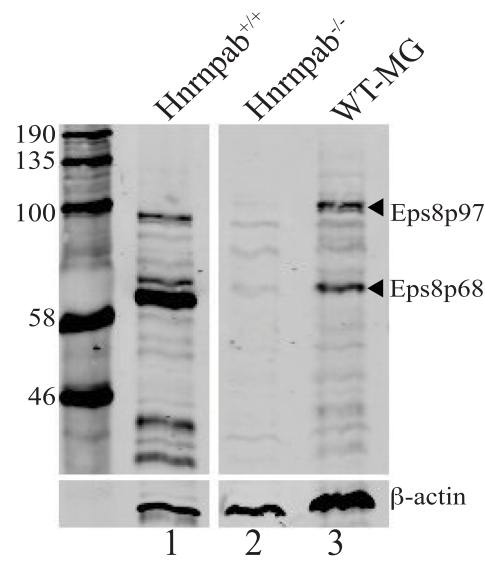

B

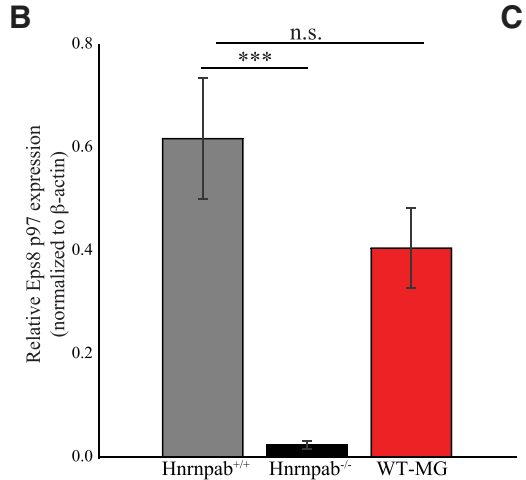

c

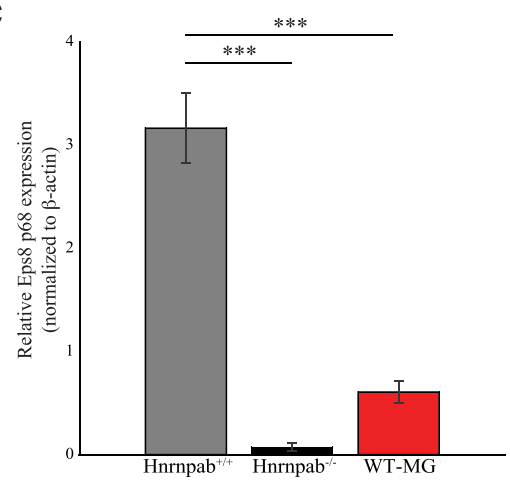

FIGURE 4. Hnrnpab regulates Eps8 expression. (A) A representative western blot of Eps8 expression in Hnrnpab ${ }^{+/+}$INCs (lane 1), Hnrnpab ${ }^{-/-}$INCs (lane 2), and Hnrnpab ${ }^{-/-}$INCs with WT-MG (lane 3). $\beta$-actin protein levels were probed to control for variation in loading. (B) Quantitation of the average Eps8p97 protein expression and (C) quantitation of the average Eps8p68 protein expression from western blots of several independent experiments as follows: Hnrnpab ${ }^{+/+} n=6 ; H_{n r n p a b}{ }^{-/} n=7 ; H_{n r n p a b}{ }^{-/-}$INCs with WT-MG $n=5$. P-values were calculated with one-way ANOVA followed by pairwise $t$-test with Bonferroni correction. Error bars represent standard error. $\left(^{* *}\right) P<0.001$.

however there was no significant decrease in the half-life of Eps8 in Hnrnpab ${ }^{+/+}$and Hnrnpab ${ }^{-/-}$INCs (Supplemental Fig. S2).

To confirm the change in Eps8 transcription we performed single molecule RNA fluorescence in situ hybridization (smRNA-FISH) on intron 2 of Eps8 and introns 1 and 2 of Actb to detect active transcription sites (Zhang et al. 1994; Shaffer et al. 2013). We observed 5.6-fold fewer Eps8 transcription sites in Hnrnpab ${ }^{-1-}$ INCs (0.038 sites/ cell) compared to Hnrnpab ${ }^{+/+}$INCs (0.214 sites/cell, Fig. $6 \mathrm{E})$. Importantly, this number was restored upon reexpression of the WT-MG (0.181 sites/cell, not significantly different from Hnrnpab ${ }^{+/+}$INCs, Fig. 6E). There was no significant difference in the number of Actb transcription sites observed among Hnrnpab ${ }^{+/+}$INCs (2.011 sites/ cell), Hnrnpab-/- INCs (2.334 sites/cell), and HnrnpabINCs with WT-MG (2.383 sites/cell, Fig. 6D,E). These results corroborate the measurement of pre-mRNA levels and confirm that Hnrnpab regulates Eps8 transcription in INCs.

\section{DISCUSSION}

\section{Hnrnpab regulates neural cell motility through regulation of Eps8}

We have previously shown Hnrnpab plays a role during neural development and in suppressing excitotoxic neuron cell death following glutamate stimulation. In this paper we discovered a role for this RBP in promoting neural cell motility. To identify the reason why Hnrnpab ${ }^{-/-}$neural cells are less motile than Hnrnpab ${ }^{+/+}$cells, we performed RNA-seq analysis and revealed a large number of gene expression changes, similar to what was observed in the hippocampus of Hnrnpab ${ }^{-1-}$ mice (Sinnamon et al. 2012). By relating the most significant of the gene expression changes to annotated gene functions, we were able to home in on Eps8 as the gene most likely responsible for Hnrnpab's effect on cell motility. We found that cell motility could be corrected by reexpressing both isoforms of Hnrnpab, but not with either isoform on its own (Fig. 2A). Moreover, simply replacing Eps8 in Hnrnpab-/- INCs was sufficient to restore cell motility, consistent with this single gene expression change being responsible for Hnrnpab's role in INC cell motility (Fig. 5). We have also quantified Eps8 gene expression in the presence of either Hnrnpab1 or Hnrnpab2 on its own and neither of these restores Eps8 cell motility, extending the correlation of Eps8 expression with cell motility (Supplemental Fig. S3).

\section{Hnrnpab regulates cell motility and Eps8 gene expression in vivo}

The SVZ provided a very attractive target to look for Hnrnpab function, since expression of Hnrnpab mRNA is enriched in this region (Rushlow et al. 1999; Lein et al. 2007). Cells migrating out from an SVZ explant are affected by Hnrnpab knockout and the INC model we used allowed us to establish a clear role for Hnrnpab in cell motility (Figs. 1 and 2). INCs are produced from newborn mouse forebrain cultures, where NPCs are likely to be the most abundant type of proliferating cells that would be subject to immortalization. Since INCs and SVZ have a similar change in cell motility, we then hypothesized that this would be 
A

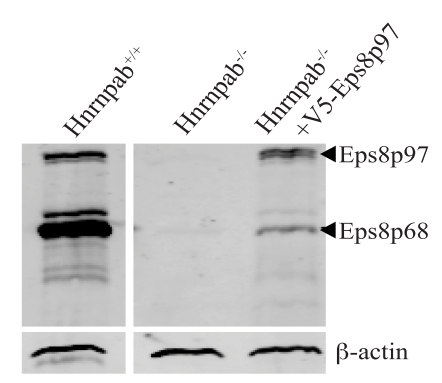

B

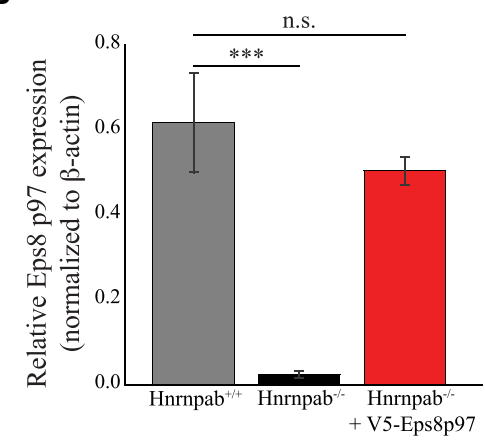

C

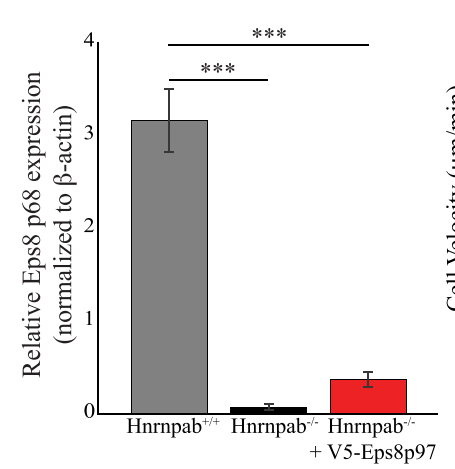

D

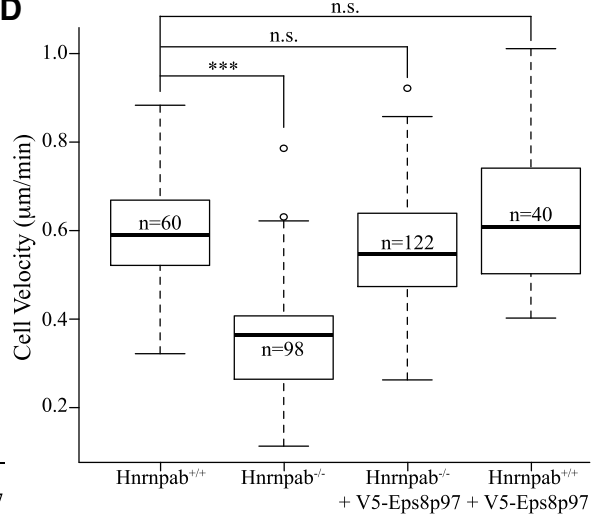

FIGURE 5. Expression of Eps8 restores cell motility defect in Hnrnpab-/- INCs. (A) Western blot of Eps8p97 expression in Hnrnpab ${ }^{+/+}$INCs (lane 1), Hnrnpab ${ }^{-/-}$INCs (lane 2), and Hnrnpab $^{-1-}$ INCs expressing V5 epitope tagged Eps8p97 INCs (lane 3). $\beta$-actin protein levels were probed to control for loading. (B) Quantitation of Eps8p97 protein levels and (C) quantitation of Eps8p68 protein levels from western blots. Protein extraction was performed from two independent cultures and each extraction was analyzed in triplicate. Error bars represent standard error. (D) Box and whisker plot of cell velocity in Hnrnpab ${ }^{+/+}$and Hnrnpab ${ }^{-/-}$ INCs expressing V5-Eps8p97 as indicated below the data. Data from Hnrnpab ${ }^{+/+}$INCs and $H_{n n n p a b}{ }^{-1-}$ INCs is the same as in Figure 2A. P-values were calculated using one-way ANOVA followed by pairwise $t$-test with Bonferroni correction. (***) $P<0.001$.

reflected in similar changes in motility gene expression. The NPCs, which would normally be a small fraction of the population in most regions of the brain, are more highly represented when the SVZ is dissected from the rest of the cerebral cortex (Walker and Kempermann 2014). The results from both migration assays and Eps8 mRNA expression in the SVZ corresponded to what we observed in INCs, consistent with the hypothesis Hnrnpab is regulating cell migration in NPCs of the SVZ through Eps8 gene expression. Interestingly, this regulation is not in every tissue, since Eps8 was not clearly decreased in either lung or liver, both of which do express Hnrnpab. In the hippocampus, we also observed a decrease that was not as robust as in the SVZ. We think this is because the dentate gyrus of the hippocampus contains another population of NPCs that is smaller fraction than in the SVZ (Riquelme et al. 2008; Zhao et al. 2008). We speculate that Hnrnpab still regulates Eps8 in NPCs in this brain region, therefore the effect on Eps8 expression from the whole tissue is smaller than in the SVZ.
Eps8 is a conserved gene, it first had an established role in mitogenic signaling through growth factor receptors and it is often found overexpressed in several types of cancer (Li et al. 2013). Eps8 was initially identified as a protein phosphorylated by activation of the EGF receptor, and it was subsequently shown to participate in signaling pathways downstream from EGFR (Fazioli et al. 1993; Castagnino et al. 1995). EGFR is known to play a role in neuronal migration in the developing nervous system and this is likely to involve Eps8 (Caric et al. 2001). Eps8's role in cell motility involves the ability to activate Rac GTPase and/or regulation of the actin cytoskeleton through interaction with other factors in order to bind directly to actin. Both of these mechanisms can regulate the actin rich structures required for cell motility (Disanza et al. 2004; Frittoli et al. 2011; Mitra et al. 2011). Eps8 can therefore be viewed as an important effector for growth factor signaling pathways that impacts cell motility and actin remodeling in many cellular contexts (Scita et al. 1999).

Our evidence demonstrated that regulation of Eps8 by Hnrnpab is sufficient to regulate neural cell migration. There is corroborating evidence that Eps8 expression facilitates neural cell motility; in rat neural cell lines and in SVZ explants Eps8 has been shown to function in NRG1-Erb4 stimulated migration (Fregnan et al. 2011). Erb4 is a EGFR family receptor, and the members of this family signal through very similar transduction pathways likely to include Eps8 (Kennedy et al. 2016). Moreover, the regulation of Eps8 in NPCs provides a likely mechanism underlying our previously reported decrease of Nestin expressing cells in neurosphere cultures from mice lacking Hnrnpab. EGF is the primary growth factor used for maintenance of neural precursor cells in vitro (Weiss et al. 1996), and we consider it is likely that the effect of Hnrnpab knockout on Eps8 results in a defective EGF signal for precursor maintenance. Evidence also supports the possibility that an effect of Hnrnpab on the EGF signaling pathway can account for Hnrnpab's role in the survival of neurons following excito-toxicity (Kornblum et al. 1998; Sibilia et al. 1998; Wagner et al. 2006). Although there is strong support for the change in migration area of $\mathrm{Hnrnpab}^{-1-} \mathrm{SVZ}$ explants being directly due to a change in cell motility we have 


\section{A}

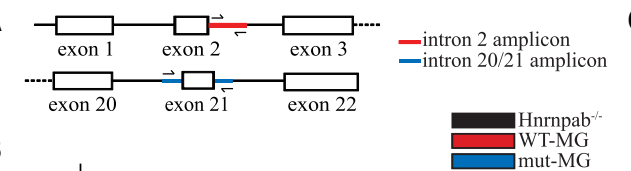

C
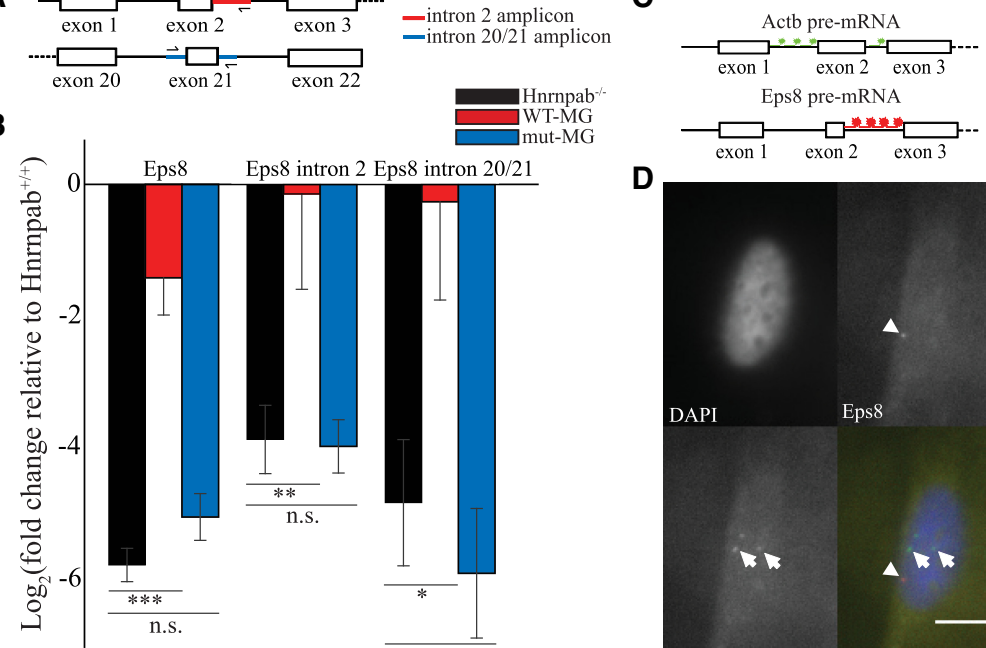

Eps8 intron 2 Eps8 intron 20/21

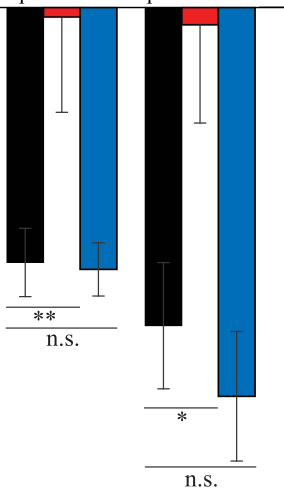

E
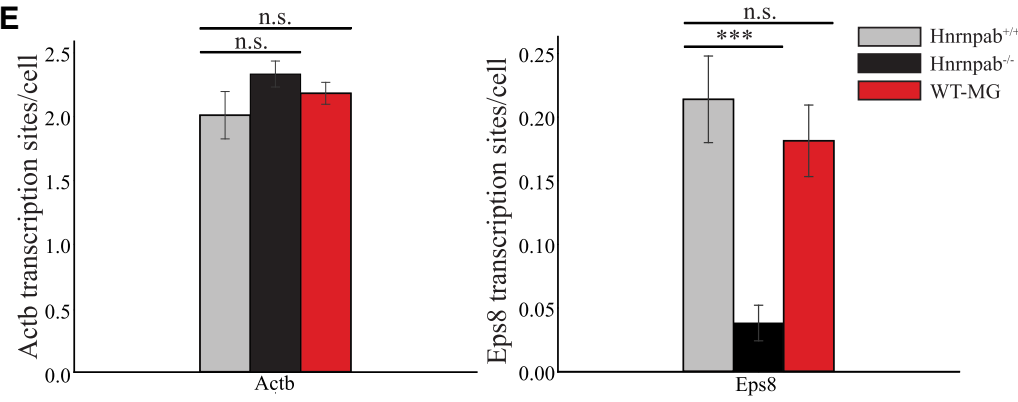

FIGURE 6. Hnrnpab regulates the transcription of Eps8. (A) Diagram of Eps8 gene regions for RT-QPCR quantitation indicated in red (intron 2) and blue (intron 20/21). (B) Expression of Eps8 mRNA and Eps8 pre-mRNA were measured at intron 2 and intron 20/21 as indicated on the top of the chart. Quantification and display of the results is as described for Figure 3A. (C) Diagram indicating the location of the FISH probes targeted to introns 1 and 2 of Actb pre-mRNA and intron 2 of Eps8 pre-mRNA. (D) A representative image of the FISH data for Eps8 and Actb. Scale bar $=10 \mu \mathrm{m}$. Arrows point to Actb sites, arrowhead points to Eps8 site. (E) Quantitation of Actb (left chart) and Eps8 (right chart) average transcription sites per cell for Hnrnpab ${ }^{+/+}$ INCs, Hnrnpab ${ }^{-/-}$INCs, and Hnrnpab ${ }^{-/-}$INCs expressing WT-MG as indicated. The $n$-values are the same for Actb and Eps8 between Hnrnpab ${ }^{+/+}$, Hnrnpab $^{-/-}$, and WT-MG. For number of fields, Hnrnpab ${ }^{+/+} n=25, H n r n p a b^{-/-} n=26$; WT-MG $n=21$. For number of cells, Hnrnpab $^{+/+} n=221 ; H_{n r n p a b}{ }^{/-} n=195 ;$ WT-MG $n=282$. The error bars represent standard error of the mean for number of image fields analyzed. $P$-values were calculated using oneway ANOVA followed by pairwise t-test with Bonferroni correction. $\left(^{* * *}\right) P<0.001,\left(^{* *}\right) P<$ $0.01,(*) P<0.05$

not ruled out contributions from cell death or cell proliferation in the reduced migration area.

\section{Hnrnpab nucleic acid binding is important for regulation of Eps8 transcription}

The presence of the tandem RRMs first presents the possibility that Hnrnpab regulates Eps8 gene expression at the level of RNA, yet the mRNA half-life could not account for the decrease in Eps8 mRNA seen in Hnrnpab-/- INCs (Supplemental Fig. S2). A decrease in Eps8 pre-mRNA and in Eps8 transcription sites clearly accounts for the decrease in Eps8 mRNA we observe, therefore we are certain that transcription is decreased in the absence of
Hnrnpab. In mice, there are two separate promoters that give rise to the Eps8 isoforms, the p97 promoter and $\mathrm{p} 68$ promoter regions. By restoring Hnrnpab, the p97 isoform returned to normal levels while p68 was only weakly restored, suggesting that both promoters could be the target of Hnrnpab function. However, restoring only the p97 isoform resulted in a similar weak appearance of the p68 isoform at the protein and RNA level, independent of Hnrnpab. Therefore the expression of p97 itself is what leads to this weak restoration of 068 rather than Hnrnpab. We conclude that Hnrnpab probably targets only the p97 Eps8 promoter that is found in both mouse and human cells. Whether Hnrnpab regulates Eps8 in human NPCs requires further experiments.

Our data show that the Hnrnpab RRMs are required to activate Eps8 transcription, consistent with nucleic acid binding playing a central role in Hnrnpab activity. Among the simplest mechanisms for Hnrnpab regulating Eps8 is as a DNA binding transcription factor, but there is skepticism about RNA-binding proteins being able to function in this manner. The original characterization of Hnrnpab1's nucleic acid binding activity indicated no detectable interaction with double stranded DNA and the mechanisms by which RRMs have been found to interact with nucleic acid are not consistent with double stranded DNA binding (Kumar et al. 1987; Daubner et al. 2013). When the nucleic acid elements contacted by an RRM are not specific to RNA, an RRM can recognize single stranded DNA just as well (Cléry et al. 2008). It is therefore more plausible that Hnrnpab can act on ssDNA at the Eps8 promoter. A weak ability of single stranded DNA to compete Hnrnpab1 from hnRNA has been demonstrated, and single stranded DNA competed dsDNA binding much more effectively than dsDNA (Kumar et al. 1987; Murgatroyd et al. 2004). But promoter DNA should be largely double stranded and nucleosome associated, so it is not clear how single stranded DNA at the Eps8 promoter would be produced for Hnrnpab to function. We note that Hnrnpab1 was purified based on its ability to stoichiometrically disrupt RNA secondary structure, 
and recombinant Hnrnpab2 was able to promote S1 nuclease digestion of double stranded DNA, suggestive of unwinding activity (Kumar et al. 1987; Murgatroyd et al. 2004). Hnrnpab2 was also capable of disrupting G-quartet DNA in vitro (Kumar et al. 1987; Sarig et al. 1997; Weisman-Shomer et al. 2002). It is possible that Hnrnpab may be acting analogous to the multiple K-homology $(\mathrm{KH})$ domain RBP far upstream element binding protein 1 (FUBP1) in transcription of the c-myc gene. FUBP1 binds ssDNA of the far upstream regulatory element of the cmyc promoter in order to activate c-myc transcription, where ssDNA may be produced directly by FUBP DNA binding, or as a result of supercoiling produced by preinitiation/mediator complex interaction with the promoter (Bazar et al. 1995; Zhang and Chen 2013; Quinn 2017).

Several studies that used oligo-deoxyribonucleotide (ODN) affinity chromatography of transcriptional control elements discovered Hnrnpab as putative DNA binding transcription factors from human cell lines, and most of these studied only Hnrnpab2 (Smidt et al. 1995; Wang and Parrish 1999; Leverrier et al. 2000; Mikheev et al. 2000; Yabuki et al. 2001; Gao et al. 2004; Murgatroyd et al. 2004; Aranburu et al. 2006). There remains no biochemical consensus for an Hnrnpab sequence that has been found among these ODN sequences as would be expected. Moreover, Hnrnpab-dependent changes in transcription reporter activity in cells typically depended on Hnrnpab high copy plasmid based expression or knockdown plasmids, and could not rule out indirect effects on reporter transcription activity, for example through unidentified Hnrnpab-dependent changes in cellular signaling pathways and/or transcription factor activity that indirectly impacted reporter gene expression. Our data show regulation at the endogenous Eps8 locus with physiological levels of Hnrnpab.

It is interesting to note that the Hnrnpab paralog, AUF1/hnRNP D has been reported to promote transcription of the mTert gene in mouse embryonic fibroblasts, as well as the MEF2C gene during myogenesis, being also shown to promote translation of the MEF2C mRNA in the same cells (Pont et al. 2012; Panda et al. 2014). Also, both AUF1/hnRNP D and Hnrnpab binding correlate with activity of a transcription repressor element within the late promoter $\mathrm{P}_{811}$ of the HPV18 virus (Wang et al. 2017). Immunolabeling of the Xenopus Hnrnpab ortholog, 40LoVe, in oocytes decorated the actively transcribing lampbrush chromosomes, consistent with association of 40LoVe with chromatin (Czaplinski et al. 2005). These are all indications that an uncharacterized role of Hnrnpab more directly in transcription, perhaps acting on DNA itself, may extend to its orthologs and paralogs. Regardless of the mechanism for how Hnrnpab is regulating Eps8, this mechanism of action must be cell-type specific. There are clearly tissues in Hnrnpab ${ }^{-/-}$mice where Eps8 mRNA is found at normal levels so this is not a constitutive transcription activity.
There are also many speculative possibilities for Hnrnpab to function in INC and NPCs in an Eps8 transcription promoter complex that can still involve direct RNA binding, such as ncRNA or IncRNA or even nascent RNA pol II RNA. There are now several examples of RBPs affecting RNA pol II transcription by regulating pTEFb activity through the 7SK RNA, and Hnrnpab is among the RBPs that interact with the MEPCE component of the 7SK snRNP (Jeronimo et al. 2007; McNamara et al. 2013; Giraud et al. 2014; Lemieux et al. 2015; Briese et al. 2018). It also is possible that Hnrnpab regulates the expression or function of an unidentified transcription factor that acts in a cell-type specific manner. Eight of the most significantly affected genes in our RNA-seq analysis were transcription factors based on gene ontology annotations and functional domains. We screened these with RTQPCR but none of these were corrected by restoring Hnrnpab expression, and thus cannot explain the effect on Eps8 transcription (Supplemental Table SII). It remains possible that there is a factor below the threshold of detection that is regulated by Hnrnpab at the RNA level and thus escaped identification in RNA-seq.

\section{Two isoforms of Hnrnpab are required for regulation of Eps8 transcription}

One of the biggest surprises from our studies was that neither individual isoform of Hnrnpab could fulfill the function of the gene knockout for cell motility or Eps8 expression. The two Hnrnpab isoforms are identical with the exception of the glycine-tyrosine (GY) rich region encoded by exon7 that is not included in Hnrnpab2 transcripts. The Hnrnpab gene has two tandem RRMs that are identical between Hnrnpab1 and Hnrnpab2 and therefore should confer the same capacity to bind RNA, since the alternative splicing of exon7 does not alter their RRMs. The fact that neither isoform can function alone suggests that nucleic acid recognition of Hnrnpab cognate RNA sequence is not enough for gene function. We have reported elsewhere that Hnrnpab1 and Hnrnpab2 have different ranges of nucleic acid binding targets, since Hnrnpab1 could specifically recognize the Actb mRNA zipcode, whereas Hnrnpab2 was not specific (J Sinnamon, AA Lampasona, CA Waddell, K Czaplinski, in prep.). This means that although Hnrnpab1 has a conserved role in trafficking mRNA, the Hnrnpab gene likely has multiple functions. Our data does not rule out that Eps8 mRNA is trafficked by Hnrnpab in the cytoplasm, but since our screen was for factors affected at the level of mRNA and rescue by Eps8 alone doesn't require the 3'UTR, Eps8 mRNA trafficking should not play a role in INC cell motility. Narrowing down the direct molecular target of Hnrnpab activity for regulation of Eps8 transcription will be necessary to dissect the contribution of each isoform to Eps8 transcription in INCs and NPCs. 


\section{MATERIALS AND METHODS}

\section{Expression constructs and cell culture protocols}

Tat- and rev-dependent lentiviral vectors were used for all constructs (pHAGE vector, Mostoslavsky et al. 2006; Sinnamon et al. 2012). pHAGE-CbU-3xFlag-HnrnpabMG was constructed by amplifying the first four exons from Hnrnpab cDNA, adding the triple-flag epitope and amplifying exons 5-8 in the open reading frame from genomic DNA to include introns. The Hnrnpab minigene cassette was inserted in the antisense orientation with respect to the lentiviral elements described in Figure $2 \mathrm{~B}$ to retain the intron in the pro-viral genome (Cooper et al. 2015; Poling et al. 2017). The mut-MG was constructed by site directed mutagenesis of pHAGE-CbU-3xFlag-HnrnpabMG plasmid using geneblocks (IDT Inc.) to mutate four conserved phenylalanines in the RNP2 motifs to valines. WT-MG and mutMG lentivirus cassettes coexpress YFP in the reverse orientation use as a marker for infected cells. pHAGE-UbC-3xFlag-mCherryIRES-V5-Eps8p97 was constructed using a pHAGE-UbC-3xFlagMCS-IRES-mChPuro vector. mCherry sequence flanked with $\mathrm{Xbal}$ and Xhol restriction site sequences was generated via add-on PCR and inserted into the vector cut with $\mathrm{Xbal}$ and Xhol to construct pHAGE-UbC-3xFlag-mCherry-IRES-mChPuro. Eps8p97 with an amino-terminal V5 epitope flanked by Ndel and Clal restriction sites was generated by add-on PCR and inserted downstream from the EMCV IRES of pHAGE-UbC3xFlag-mCherry-IRES-mChPuro using Ndel and Clal.

\section{Cell culture}

All cell lines were grown in Dulbecco's modified Eagle medium (DMEM, Corning) containing $4.5 \mathrm{~g} / \mathrm{L}$ glucose, L-glutamine and sodium pyruvate supplemented with $10 \%$ FBS and 1:1000 gentamicin. INCs were passaged every other day at a density of $2.5 \times$ $10^{5}$ cells per $10 \mathrm{~cm}$ plate. HEK 293T-17 cells were passaged every other day at a density of $7.5 \times 10^{5}$ cells per $10 \mathrm{~cm}$ plate.

\section{Creating immortalized neural cells (INCs)}

First, the Hnrnpab ${ }^{\text {Gt(AV0462)Wtsi }}$ allele and the Actb ${ }^{24 \times M B S}$ allele were backcrossed 10 generations on C57/BL6 mice (Taconic Biosciences, Lionnet et al. 2011; Sinnamon et al. 2012). These mice were then crossed to produce Hnrnpab ${ }^{\text {Gt(AV0462)Wtsi }}$ with homozygous Actb ${ }^{24 \times M B S / 24 \times M B S}$ background, and these mice were mated to create Hnrnpab ${ }^{+/+}, \mathrm{Hnrnpab}^{+/ G t(A V 0462) W t s i}\left(\mathrm{Hnrnpab}^{+/-}\right)$, and Hnrnpab Gt(AV0462)Wtsi/Gt(AV0462)Wtsi $\left(\right.$ Hnrnpab $^{-/-}$) littermates. The INCs used in this study derive from these mice. The cerebral cortex from Hnrnpab ${ }^{+/+}$and Hnrnpab ${ }^{-/-}$newborn postnatal day 0 (P0) mice were dissected, the meninges removed. This was minced with a razor blade then dissociated with Trypsin and plated on tissue culture dishes coated with 1:1000 dilution of ECM gel into DMEM (Sigma, E1270). One day after plating the cells were detached, and 2.5 million cells were seeded into six-well dishes coated with ECM as before. The following day, cells were transfected with the $2 \mu \mathrm{g}$ of SV4O T antigen vector using Lipofectamine 2000 (2:1 reagent to DNA) and continually maintained in DMEM containing $10 \%$ FBS with $10 \mu \mathrm{g} / \mathrm{mL}$ gentamicin until signs of immortalization appeared (Lu et al. 2004). INCs were maintained as a pool of all immortalized cells and were exam- ined by immunoblot and immunofluorescence to confirm expected Hnrnpab expression.

\section{Stable expression in INCs}

Recombinant lentivirus-like particles (LVPs) were created by cotransfecting HEK 293T-17 cells with lentiviral vector and lentivirus packaging plasmids expressing gag/pol, cmv/rev, tat, and VSG-G as we described previously, with the following adaptations (Sinnamon et al. 2012). The concentrated LVP pellet was respuspended in $1 \mathrm{~mL}$ of DMEM (without serum) at $4^{\circ} \mathrm{C}$ for $1 \mathrm{~h}$. Resuspended lentiviral particles were aliquoted into three microcentrifuge tubes of $330 \mu \mathrm{L}$ aliquots. LVPs were either used directly or stored at $-80^{\circ} \mathrm{C}$. Cells to be infected were plated at $10 \%-20 \%$ confluency in a 12 well dish coated with 1:100 poly- $\mathrm{L}-$ Lysine at least $2 \mathrm{~h}$ prior to infection. After at least $2 \mathrm{~h}$ incubation at $37^{\circ} \mathrm{C}$ $5 \% \mathrm{CO}_{2}$, cells to be infected were rinsed once with DMEM to remove serum. One aliquot $(330 \mu \mathrm{L})$ of lentiviral particles in serum free DMEM was used per infection after adding $6 \mu \mathrm{g} / \mathrm{mL}$ of polybrene and kept on the cells for at least $2 \mathrm{~h}$ at $37^{\circ} \mathrm{C} 5 \% \mathrm{CO}_{2}$, gently agitating every $15 \mathrm{~min}$. Afterwards, viral media was removed and replaced with full-serum media. After $3 d$, cells were observed under a fluorescent microscope to look for positive infection. When expression was lower than $60 \%$ positive cells, the population was FACS sorted based on the fluorescent protein coexpressed by the LVP.

\section{Monolayer scratch assay}

A total of $1.5 \times 10^{5}$ INCs were plated on to poly-L-Lysine coated $\left(10 \mu \mathrm{g} / \mathrm{mL}\right.$ in $\left.\mathrm{H}_{2} \mathrm{O}\right)$ Delta $\mathrm{T}$ dishes (Bioptechs). Cells were grown one day to become a monolayer. The following day, the media was changed to Cell Imaging Solution (20 mM Hepes, $\mathrm{pH} 7.4$, $2.5 \mathrm{mM} \mathrm{KCl}, 140 \mathrm{mM} \mathrm{NaCl}, 5 \mathrm{mM}$ glucose, $1.4 \mathrm{mM} \mathrm{CaCl}_{2}$, $0.5 \mathrm{mM} \mathrm{MgCl}_{2}$ ) with $10 \% \mathrm{FBS}$ following the scratch to image without the need for $5 \% \mathrm{CO}_{2}$ and incubated at $37^{\circ} \mathrm{C}$ for $20 \mathrm{~min}$. The Delta $T$ dish was then mounted into the stage holder and a scratch was made on the dish with a p20 pipette tip. The Delta T dishes were kept at $37^{\circ} \mathrm{C}$ in the Biotechs DeltaT stage holder using a heated cover. Time lapse images of multiple locations were taken every $5 \mathrm{~min}$ for $6 \mathrm{~h}$ at $60 \times$ magnification as cells moved into the wound. Cell velocity was calculated using the ImageJ cell tracking software MTrackJ to track the distance individual cells traveled over the 6-h time window (Meijering et al. 2012). Cell velocities were plotted using box and whisker plots. For all box and whisker plots, the thick black line indicates the median, the box indicates the interquartile range, and the whiskers indicate the range.

\section{Cellular extract preparation}

\section{Cell lysis for Hnrnpab western blot}

Nuclear fraction of cells were isolated to measure Hnrnpab expression. A total of $2.5 \times 10^{5} \mathrm{INCs}$ were plated in $10 \mathrm{~cm}$ dishes and incubated for $48 \mathrm{~h}$. Cells were scraped and washed two times in wash buffer $(10 \mathrm{mM}$ HEPES, $150 \mathrm{mM} \mathrm{NaCl}, 10 \mathrm{mM}$ EDTA, $0.5 \mathrm{mM}$ PMSF, 1× Protease Inhibitor Cocktail [PIC, Protease Arrest, G Biosciences]). Cell pellet was resuspended in hypotonic buffer (10 mM HEPES, $3 \mathrm{mM} \mathrm{MgCl}$, $0.1 \mathrm{mM} \mathrm{BME,} 10 \mathrm{mM} \mathrm{NaCl}$, $2 \times \mathrm{PIC}$ ) and incubated on ice for $10 \mathrm{~min}$. Cell suspension was 
homogenized through a $261 / 2$ gauge syringe 10 times. $\mathrm{NaCl}$ concentration was adjusted to $300 \mathrm{mM}$, and the cell suspension was incubated for $20 \mathrm{~min}$ on ice. The lysate was spun down and the supernatant was separated on an SDS PAGE gel as described below.

\section{Cell lysis for Eps8 western blot}

A total of $2.5 \times 10^{5} \mathrm{INCs}$ were plated in $10 \mathrm{~cm}$ dishes and incubated for $48 \mathrm{~h}$. The cells were trypsinized and washed with ice cold PBS. Cell pellets were resuspended in a lysis buffer $(150 \mathrm{mM}$ $\mathrm{NaCl}, 50 \mathrm{mM}$ HEPES $\mathrm{pH} 7.4,25 \mu \mathrm{g} / \mathrm{mL}$ Digitonin, $1 \mathrm{M}$ Hexylene glycol, 2x PIC) and incubated for 10 min rotating at $4^{\circ} \mathrm{C}$. Cell lysates were centrifuged at $2000 \mathrm{~g}$ for $10 \mathrm{~min}$ at $4^{\circ} \mathrm{C}$. The supernatant contained the cytoplasmic fraction. The pellet was resuspended in a membrane lysis buffer $(150 \mathrm{mM} \mathrm{NaCl}$, 50 mM HEPES, pH 7.4, 1\% Igepal, 1 M Hexylene glycol, 2×PIC) and incubated on ice for $30 \mathrm{~min}$. Membrane lysates were spun at $4000 \mathrm{~g}$ for $10 \mathrm{~min}$ at $4^{\circ} \mathrm{C}$. The resulting supernatant contained the membrane fraction, which was used to quantify Eps8 expression (Baghirova et al. 2015).

\section{Western blotting}

To analyze protein fractions by western blot, protein concentrations were measured using the Pierce BCA assay, using Bovine Serum Albumin (BSA) as a standard, according to the manufacturer's protocol. 10\% (Eps8) or 12\% (Hnrnpab) acrylamide TrisGlycine gels were used for SDS-PAGE using standard protocols. Fifty micrograms of protein extract was loaded in each well. After separation, PAGE gels were transferred to a nitrocellulose membrane After transfer the membrane was blocked in $5 \%$ milk in PBS with $0.05 \%$ Tween-20 (PBST) at room temperature for $1 \mathrm{~h}$. Blots were incubated with primary antibody overnight rotating at $4^{\circ} \mathrm{C}$ in $5 \%$ milk in PBST. The Hnrnpab antibody (Santa Cruz, cat. no. SC98810) was used at 1:400 dilution, the Eps8 antibody (BD, cat. no. 610143) was used at 1:400 dilution and the $\beta$-actin antibody (Sigma, A2228) was used at 1:1000 dilution. Blots were washed with $1 \times$ PBST three times for 5 min and incubated with 1:2000 dilution of secondary antibodies (IR700 donkey antimouse) in 1× PBST for 45 min in the dark. Following secondary antibody incubation, blots were washed in $1 \times$ PBST for 5 min three times and imaged using a LICOR Odyssey. Relative protein expression from western blots were quantified using ImageJ measure gels tool normalized to $\beta$-actin expression. For Hnrnpab, average background was calculated using ImageJ measure gels tool and subtracted from measurements of Hnrnpab expression in Hnrnpab $^{+/+}$and WT-MG prior to $\beta$-actin normalization.

\section{RNA sequencing and RT-OPCR protocols}

\section{RNA-seq}

Total cellular RNA was isolated from three independent preparations each of Hnrnpab ${ }^{+/+}$and Hnrnpab ${ }^{-/-}$INCs using commercially purchased TRI-Reagent (Chomczynski and Sacchi 1987). The samples were DNase treated with Turbo DNase (Ambion Technologies) and purity was measured using a bioanalyzer. Samples had RIN value of 9.64 or greater. RNA-seq was per- formed by the New York Genome Center. Sequencing libraries were created using the KAPA Stranded RNA-seq Kit with RiboErase for rRNA depletion. Libraries were sequenced using a $2 \times 125$ bp rapid run in an Illumina HiSeq2500 and reads were mapped to the mouse genome mm10. DESeq2 differential gene expression analysis and CuffDiff differential gene expression analysis were performed to identify genes with a q-value of $<0.01$ that were changed twofold or more. Only genes that fit this criteria in both analyses were considered for further analysis. A subset of these genes was selected for validation by QPCR as described in the text.

\section{RT-QPCR}

RNA for RT-QPCR was isolated using a commercially purchased TRI Reagent. A total of 500-800 ng total RNA from tissues or 1 $\mu \mathrm{g}$ total RNA from INCs was converted to cDNA using mMuLV reverse transcriptase and hexanucleotides and polydT as primers (New England Biolabs). 1/20th of the cDNA reaction was analyzed using qRT-PCR using PowerUp Sybr green Master Mix (Applied Biosystems). Primers were designed to anneal at $60^{\circ} \mathrm{C}$ using $\mathrm{NCBI}$ primer design function. Melting curves were generated for each primer set used and all primers were screened using standard PCR to check for amplification of one single band of the expected size. Reactions were carried out in Applied Biosystems StepOne PCR machine. Data were analyzed using the $\Delta \Delta C_{T}$ method compared to Snrnp70 as a reference control. Actb primers were also used to ensure there were no differences in Snrnp70 expression between genotypes (Supplemental Fig. S4).

\section{Actinomycin D treatment}

Actinomycin D was added to cells at a final concentration of $5 \mu \mathrm{g} /$ $\mathrm{mL}$ for times indicated on graph. Cells were washed with $1 \times$ PBS and RNA was isolated, converted to CDNA, and analyzed using RT-QPCR as described above, using Actb as a reference control. The amount of RNA relative to time 0 was plotted to measure the half-life of Eps8 mRNA.

\section{Intron RNA fluorescence in situ hybridization (intron RNA-FISH)}

INCs were plated at 40\%-60\% confluence on poly-L-Lysine coated $18 \mathrm{~mm}$ coverslips $1 \mathrm{~d}$ before fixation. Cells were fixed using a 3:1 mixture of methanol:acetic acid for $10 \mathrm{~min}$ at room temperature. Cells were washed twice with $2 \times \mathrm{SSC} / 10 \%$ formamide in nuclease free water. $12.5 \mathrm{nM}$ of Stellaris probes from Biosearch Technologies targeted against intron 2 of Eps8 (Сy3) and introns 1 and 2 of Actb (Cy5) were hybridized in $100 \mu \mathrm{L}$ of hybridization buffer (10\% formamide, 2xSSC, $10 \%$ Dextran Sulfate) for $2 \mathrm{~h}$ at $37^{\circ} \mathrm{C}$. Coverslips were washed in $2 \times \mathrm{SSC} / 10 \%$ formamide for $30 \mathrm{~min}$ at $37^{\circ} \mathrm{C}$. Coverslips were then incubated in $10 \mu \mathrm{g} / \mathrm{mL}$ DAPI in $2 \times$ $\mathrm{SSC} / 10 \%$ formamide for $15 \mathrm{~min}$ at $37^{\circ} \mathrm{C}$. After DAPI staining, coverslips were washed twice in $2 \times$ SSC and mounted on to coverslips using VectaShield hard set antifade mounting medium. Slides were cured overnight in the dark at room temperature and imaged the following day. Image fields were selected in the Cy5 channel (Actb) to prevent bias of only selecting image fields with Eps8 transcription sites. Because all image fields with cells have Actb sites, this technique does not bias image selection for inclusion of Actb 
sites. The number of transcription sites per cell was quantified by counting the total number Actb sites and Eps8 sites and dividing by the total number of cells in the field. The error bars represent standard error of the mean for number of image fields analyzed. The $n$-values are the same for Actb and Eps8 between $H_{n n n p a b}{ }^{+/}, H_{n n n a b}{ }^{-1}$, and WT-MG. For number of fields, $H_{n r n p a b}{ }^{+/} n=25$, Hnrnpab ${ }^{-/-} n=26$; WT-MG $n=21$. For number of cells, Hnrnpab ${ }^{+/+} n=221$; Hnrnpab ${ }^{-/-} n=195$; WT-MG $n=282$.

\section{RNA isolation of tissues}

Newborn pups (P3-P4) were euthanized by decapitation and brains placed in ice cold Hanks Basal Salt Solution. The hippocampus, SVZ, lung, and liver were dissected as previously described (Seibenhener and Wooten 2012; Walker and Kempermann 2014). These tissues were homogenized in TRI reagent and RNA was isolated, and analyzed using RT-QPCR as described above, using Actb as a reference control.

\section{Subventricular zone explant migration assay}

Hnrnpab ${ }^{\text {Gt(AV0462)Wtsi }}$ mice after crossing 10 generations to C57/BL six mice were used for these experiments (Actb ${ }^{+/+}$background).The SVZ from the brains of P3-P4 pups was dissected, cut into pieces of 200-600 $\mu \mathrm{m}$ and plated onto Matrigel coated 24-well plates in Neurobasal with $1 \times$ B27, 0.5 mM glutaMAX, and 1:1000 primocin as previously described (Wichterle et al. 1997). Explants were incubated in $5 \% \mathrm{CO}_{2}$ at $37^{\circ} \mathrm{C}$. After $48 \mathrm{~h}$, DIC images of the neural stem cells migrating from the explant were taken. To measure average distance migrated per explant, six different measurements were taken from the explant to the furthest point migrated by NSPCs. These measurements were averaged together to obtain one average distance migrated per explant and plotted with a box and whisker plot. To measure migration area, the image was thresholded in ImageJ and the migrated NSPCs were outlined using the polygon selection tool. The explant was also outlined using the polygon selection tool, and the area was measured for both using the measurement tool. The area of the explant was subtracted from the area of the migrated NSPCs and plotted using box and whisker plots.

\section{SUPPLEMENTAL MATERIAL}

Supplemental material is available for this article.

\section{ACKNOWLEDGMENTS}

This work was supported by research funds supplied by the Stony Brook School of Medicine and a National Science Foundation CAREER award (IOS-1254146) to K.C.

Received August 27, 2018; accepted October 1, 2018.

\section{REFERENCES}

Akindahunsi AA, Bandiera A, Manzini G. 2005. Vertebrate 2xRBD hnRNP proteins: a comparative analysis of genome, mRNA and protein sequences. Comput Biol Chem 29: 13-23. doi:10.1016/ j.compbiolchem.2004.11.002
Apostolopoulou M, Kiehl TR, Winter M, Cardenas De La Hoz E, Boles NC, Bjornsson CS, Zuloaga KL, Goderie SK, Wang Y, Cohen AR, et al. 2017. Non-monotonic changes in progenitor cell behavior and gene expression during aging of the adult $\mathrm{V}$ SVZ neural stem cell niche. Stem Cell Reports 9: 1931-1947. doi:10.1016/j.stemcr.2017.10.005

Aranburu A, Liberg D, Honoré B, Leanderson T. 2006. CArG boxbinding factor-A interacts with multiple motifs in immunoglobulin promoters and has a regulated subcellular distribution. Eur $J$ Immunol 36: 2192-2202. doi:10.1002/eji.200535659

Auciello G, Cunningham DL, Tatar T, Heath JK, Rappoport JZ. 2013. Regulation of fibroblast growth factor receptor signalling and trafficking by Src and Eps8. J Cell Sci 126: 613-624. doi:10.1242/ jcs. 116228

Baghirova S, Hughes BG, Hendzel MJ, Schulz R. 2015. Sequential fractionation and isolation of subcellular proteins from tissue or cultured cells. MethodsX 2: 440-445. doi:10.1016/j.mex.2015. 11.001

Baltz AG, Munschauer M, Schwanhäusser B, Vasile A, Murakawa $Y$, Schueler M, Youngs N, Penfold-Brown D, Drew K, Milek M, et al. 2012. The mRNA-bound proteome and its global occupancy profile on protein-coding transcripts. Mol Cell 46: 674-690. doi:10.1016/j.molcel.2012.05.021

Bazar L, Meighen D, Harris V, Duncan R, Levens D, Avigan M. 1995. Targeted melting and binding of a DNA regulatory element by a transactivator of c-myc. J Biol Chem 270: 8241-8248. doi:10.1074/jbc.270.14.8241

Briese M, Saal-Bauernschubert L, Ji C, Moradi M, Ghanawi H, Uhl M, Appenzeller S, Backofen R, Sendtner M. 2018. hnRNP R and its main interactor, the noncoding RNA 7SK, coregulate the axonal transcriptome of motoneurons. Proc Natl Acad Sci 115: E2859E2868. doi:10.1073/pnas.1721670115

Bunnell TM, Burbach BJ, Shimizu Y, Ervasti JM. 2011. $\beta$-Actin specifically controls cell growth, migration, and the G-actin pool. Mol Biol Cell 22: 4047-4058. doi:10.1091/mbc.e11-06-0582

Burridge K, Wennerberg K. 2004. Rho and Rac take center stage. Cell 116: 167-179. doi:10.1016/S0092-8674(04)00003-0

Caric D, Raphael H, Viti J, Feathers A, Wancio D, Lillien L. 2001. EGFRs mediate chemotactic migration in the developing telencephalon. Development 128: 4203-4216.

Castagnino P, Biesova Z, Wong WT, Fazioli F, Gill GN, Di Fiore PP. 1995. Direct binding of eps8 to the juxtamembrane domain of EGFR is phosphotyrosine- and SH2-independent. Oncogene 10: 723-729.

Castello A, Fischer B, Eichelbaum K, Horos R, Beckmann BM, Strein C, Davey NE, Humphreys DT, Preiss T, Steinmetz LM, et al. 2012. Insights into RNA biology from an atlas of mammalian mRNAbinding proteins. Cell 149: 1393-1406. doi:10.1016/j.cell.2012. 04.031

Chomczynski P, Sacchi N. 1987. Single-step method of RNA isolation by acid guanidinium thiocyanate-phenol-chloroform extraction. Anal Biochem 162: 156-159. doi:10.1016/0003-2697(87)90021-2

Cléry A, Blatter M, Allain FH. 2008. RNA recognition motifs: boring? Not quite. Curr Opin Struct Biol 18: 290-298. doi:10.1016/j. sbi.2008.04.002

Condeelis J, Singer RH. 2005. How and why does $\beta$-actin mRNA target? Biol Cell 97: 97-110. doi:10.1042/BC20040063

Cooper AR, Lill GR, Gschweng EH, Kohn DB. 2015. Rescue of splicingmediated intron loss maximizes expression in lentiviral vectors containing the human ubiquitin $\mathrm{C}$ promoter. Nucleic Acids Res 43: 682-690. doi:10.1093/nar/gku1312

Czaplinski K, Mattaj IW. 2006. 40LoVe interacts with Vg1RBP/Vera and hnRNP I in binding the Vg1-localization element. RNA 12: 213222. doi:10.1261/rna.2820106 
Czaplinski K, Köcher T, Schelder M, Segref A, Wilm M, Mattaj IW. 2005. Identification of 40LoVe, a Xenopus hnRNP D family protein involved in localizing a TGF- $\beta$-related mRNA during oogenesis. Dev Cell 8: 505-515. doi:10.1016/j.devcel.2005.01.012

Daubner GM, Cléry A, Allain FH. 2013. RRM-RNA recognition: NMR or crystallography... and new findings. Curr Opin Struct Biol 23: 100-108. doi:10.1016/j.sbi.2012.11.006

Dichmann DS, Fletcher RB, Harland RM. 2008. Expression cloning in Xenopus identifies RNA-binding proteins as regulators of embryogenesis and Rbmx as necessary for neural and muscle development. Dev Dyn 237: 1755-1766. doi:10.1002/dvdy.21590

Ding J, Hayashi MK, Zhang Y, Manche L, Krainer AR, Xu RM. 1999. Crystal structure of the two-RRM domain of hnRNP A1 (UP1) complexed with single-stranded telomeric DNA. Genes Dev 13: 11021115. doi:10.1101/gad.13.9.1102

Disanza A, Carlier MF, Stradal TE, Didry D, Frittoli E, Confalonieri S, Croce A, Wehland J, Di Fiore PP, Scita G. 2004. Eps8 controls actin-based motility by capping the barbed ends of actin filaments. Nat Cell Biol 6: 1180-1188. doi:10.1038/ncb1199

Disanza A, Mantoani S, Hertzog M, Gerboth S, Frittoli E, Steffen A, Berhoerster K, Kreienkamp HJ, Milanesi F, Di Fiore PP, et al. 2006. Regulation of cell shape by Cdc42 is mediated by the synergic actin-bundling activity of the Eps8-IRSp53 complex. Nat Cell Biol 8: 1337-1347. doi:10.1038/ncb1502

Dizon ML, Shin L, Sundholm-Peters NL, Kang E, Szele FG. 2006. Subventricular zone cells remain stable in vitro after brain injury. Neuroscience 142: 717-725. doi:10.1016/j.neuroscience.2006. 06.050

Dormoy-Raclet V, Ménard I, Clair E, Kurban G, Mazroui R, Di Marco S, von Roretz C, Pause A, Gallouzi IE. 2007. The RNA-binding protein HuR promotes cell migration and cell invasion by stabilizing the $\beta$ actin mRNA in a U-rich-element-dependent manner. Mol Cell Biol 27: 5365-5380. doi:10.1128/MCB.00113-07

Enokizono Y, Konishi Y, Nagata K, Ouhashi K, Uesugi S, Ishikawa F, Katahira M. 2005. Structure of hnRNP D complexed with singlestranded telomere DNA and unfolding of the quadruplex by heterogeneous nuclear ribonucleoprotein D. J Biol Chem 280: 18862-18870. doi:10.1074/jbc.M411822200

Fazioli F, Minichiello L, Matoska V, Castagnino P, Miki T, Wong WT, Di Fiore PP. 1993. Eps8, a substrate for the epidermal growth factor receptor kinase, enhances EGF-dependent mitogenic signals. EMBO J 12: 3799-3808. doi:10.1002/j.1460-2075.1993. tb06058.x

Fregnan F, Petrov V, Garzotto D, De Marchis S, Offenhäuser N, Grosso E, Chiorino G, Perroteau I, Gambarotta G. 2011. Eps8 involvement in neuregulin1-ErbB4 mediated migration in the neuronal progenitor cell line ST14A. Exp Cell Res 317: 757-769. doi:10.1016/j.yexcr.2011.01.023

Frittoli E, Matteoli G, Palamidessi A, Mazzini E, Maddaluno L, Disanza A, Yang C, Svitkina T, Rescigno M, Scita G. 2011. The signaling adaptor Eps8 is an essential actin capping protein for dendritic cell migration. Immunity 35: 388-399. doi:10.1016/j. immuni.2011.07.007

Funato $Y$, Terabayashi T, Suenaga N, Seiki M, Takenawa T, Miki H. 2004. IRSp53/Eps8 complex is important for positive regulation of Rac and cancer cell motility/invasiveness. Cancer Res 64: 5237-5244. doi:10.1158/0008-5472.CAN-04-0327

Gao C, Guo H, Wei J, Mi Z, Wai P, Kuo PC. 2004. S-nitrosylation of heterogeneous nuclear ribonucleoprotein $\mathrm{A} / \mathrm{B}$ regulates osteopontin transcription in endotoxin-stimulated murine macrophages. J Biol Chem 279: 11236-11243. doi:10.1074/jbc.M313385200

Gerstberger S, Hafner M, Tuschl T. 2014. A census of human RNAbinding proteins. Nat Rev Genet 15: 829-845. doi:10.1038/ nrg3813
Giraud M, Jmari N, Du L, Carallis F, Nieland TJ, Perez-Campo FM, Bensaude O, Root DE, Hacohen N, Mathis D, et al. 2014. An RNAi screen for Aire cofactors reveals a role for Hnrnpl in polymerase release and Aire-activated ectopic transcription. Proc Natl Acad Sci 111: 1491-1496. doi:10.1073/pnas.1323535111

Gong S, Zheng C, Doughty ML, Losos K, Didkovsky N, Schambra UB, Nowak NJ, Joyner A, Leblanc G, Hatten ME, et al. 2003. A gene expression atlas of the central nervous system based on bacterial artificial chromosomes. Nature 425: 917-925. doi:10.1038/ nature02033

Gonzalez-Perez O, Alvarez-Buylla A. 2011. Oligodendrogenesis in the subventricular zone and the role of epidermal growth factor. Brain Res Rev 67: 147-156. doi:10.1016/j.brainresrev.2011.01.001

Hertzog M, Milanesi F, Hazelwood L, Disanza A, Liu H, Perlade E, Malabarba MG, Pasqualato S, Maiolica A, Confalonieri S, et al. 2010. Molecular basis for the dual function of Eps8 on actin dynamics: bundling and capping. PLoS Biol 8: e1000387. doi:10.1371/journal.pbio.1000387

Innocenti M, Frittoli E, Ponzanelli I, Falck JR, Brachmann SM, Di Fiore PP, Scita G. 2003. Phosphoinositide 3-kinase activates Rac by entering in a complex with Eps8, Abi1, and Sos-1. J Cell Biol 160: 17-23. doi:10.1083/jcb.200206079

Jeronimo C, Forget D, Bouchard A, Li Q, Chua G, Poitras C, Thérien C, Bergeron D, Bourassa S, Greenblatt J, et al. 2007. Systematic analysis of the protein interaction network for the human transcription machinery reveals the identity of the 7SK capping enzyme. Mol Cell 27: 262-274. doi:10.1016/j.molcel.2007.06.027

Kaneko N, Sawada M, Sawamoto K. 2017. Mechanisms of neuronal migration in the adult brain. J Neurochem 141: 835-847. doi:10.1111/jnc.14002

Katz ZB, Wells AL, Park HY, Wu B, Shenoy SM, Singer RH. 2012. $\beta$ Actin mRNA compartmentalization enhances focal adhesion stability and directs cell migration. Genes Dev 26: 1885-1890. doi:10.1101/gad.190413.112

Kennedy SP, Hastings JF, Han JZ, Croucher DR. 2016. The under-appreciated promiscuity of the epidermal growth factor receptor family. Front Cell Dev Biol 4: 88. doi:10.3389/fcell.2016.00088

Kislauskis EH, Zhu X, Singer RH. 1997. $\beta$-Actin messenger RNA localization and protein synthesis augment cell motility. J Cell Biol 136: 1263-1270. doi:10.1083/jcb.136.6.1263

Kornblum HI, Hussain R, Wiesen J, Miettinen P, Zurcher SD, Chow K, Derynck R, Werb Z. 1998. Abnormal astrocyte development and neuronal death in mice lacking the epidermal growth factor receptor. J Neurosci Res 53: 697-717. doi:10.1002/(SICI)1097-4547 (19980915)53:6<697::AID-JNR8>3.0.CO;2-0

Kroll TT, Swenson LB, Hartland El, Snedden DD, Goodson HV, Huber PW. 2009. Interactions of 40LoVe within the ribonucleoprotein complex that forms on the localization element of Xenopus Vg1 mRNA. Mech Dev 126: 523-538. doi:10.1016/j.mod.2009. 03.007

Kumar A, Sierakowska H, Szer W. 1987. Purification and RNA binding properties of a C-type hnRNP protein from HeLa cells. J Biol Chem 262: 17126-17137.

Lanzetti L, Rybin V, Malabarba MG, Christoforidis S, Scita G, Zerial M, Di Fiore PP. 2000. The Eps8 protein coordinates EGF receptor signalling through Rac and trafficking through Rab5. Nature 408: 374-377. doi:10.1038/35042605

Lein ES, Hawrylycz MJ, Ao N, Ayres M, Bensinger A, Bernard A, Boe AF, Boguski MS, Brockway KS, Byrnes EJ, et al. 2007. Genome-wide atlas of gene expression in the adult mouse brain. Nature 445: 168-176. doi:10.1038/nature05453

Lemieux $B$, Blanchette $M$, Monette $A$, Mouland AJ, Wellinger RJ, Chabot B. 2015. A function for the hnRNP A1/A2 proteins in transcription elongation. PLoS One 10: e0126654. doi:10.1371/journal.pone.0126654 
Leverrier S, Cinato E, Paul C, Derancourt J, Bemark M, Leanderson T, Legraverend C. 2000. Purification and cloning of type A/B hnRNP proteins involved in transcriptional activation from the Rat spi 2 gene GAGA box. Biol Chem 381: 1031-1040. doi:10.1515/ BC.2000.127

Li YH, Xue TY, He YZ, Du JW. 2013. Novel oncoprotein EPS8: a new target for anticancer therapy. Future Oncol 9: 1587-1594. doi:10.2217/fon.13.104

Liao G, Mingle L, Van De Water L, Liu G. 2015. Control of cell migration through mRNA localization and local translation. Wiley Interdiscip Rev RNA 6: 1-15. doi:10.1002/wrna.1265

Lim DA, Alvarez-Buylla A. 2016. The adult ventricular-subventricular zone (V-SVZ) and olfactory bulb (OB) neurogenesis. Cold Spring Harb Perspect Bio/ 8: a018820. doi:10.1101/cshperspect.a018820

Lionnet T, Czaplinski K, Darzacq X, Shav-Tal Y, Wells AL, Chao JA, Park HY, de Turris V, Lopez-Jones M, Singer RH. 2011. A transgenic mouse for in vivo detection of endogenous labeled mRNA. Nat Methods 8: 165-170. doi:10.1038/nmeth.1551

Lu PD, Jousse C, Marciniak SJ, Zhang Y, Novoa I, Scheuner D, Kaufman RJ, Ron D, Harding HP. 2004. Cytoprotection by preemptive conditional phosphorylation of translation initiation factor 2. EMBO J 23: 169-179. doi:10.1038/sj.emboj.7600030

Mazan-Mamczarz K, Kuwano Y, Zhan M, White EJ, Martindale JL, Lal A, Gorospe M. 2009. Identification of a signature motif in target mRNAs of RNA-binding protein AUF1. Nucleic Acids Res 37: 204 214. doi:10.1093/nar/gkn929

McKee AE, Minet E, Stern C, Riahi S, Stiles CD, Silver PA. 2005. A genome-wide in situ hybridization map of RNA-binding proteins reveals anatomically restricted expression in the developing mouse brain. BMC Dev Biol 5: 14. doi:10.1186/1471-213X-5-14

McNamara RP, McCann JL, Gudipaty SA, D'Orso I. 2013. Transcription factors mediate the enzymatic disassembly of promoter-bound 7SK snRNP to locally recruit P-TEFb for transcription elongation. Cell Rep 5: 1256-1268. doi:10.1016/j.celrep.2013. 11.003

Meijering E, Dzyubachyk O, Smal I. 2012. Methods for cell and particle tracking. Methods Enzymol 504: 183-200. doi:10.1016/B9780-12-391857-4.00009-4

Mikheev AM, Mikheev SA, Zhang Y, Aebersold R, Zarbl H. 2000. CArG binding factor $A$ (CBF-A) is involved in transcriptional regulation of the rat Ha-ras promoter. Nucleic Acids Res 28: 3762-3770. doi:10.1093/nar/28.19.3762

Ming GL, Song H. 2011. Adult neurogenesis in the mammalian brain: significant answers and significant questions. Neuron 70: 687702. doi:10.1016/j.neuron.2011.05.001

Mitra S, Lee JS, Cantrell M, Van den Berg CL. 2011. c-Jun N-terminal kinase 2 (JNK2) enhances cell migration through epidermal growth factor substrate 8 (EPS8). J Biol Chem 286: 1528715297. doi:10.1074/jbc.M109.094441

Mizuguchi H, Xu Z, Ishii-Watabe A, Uchida E, Hayakawa T. 2000. IRESdependent second gene expression is significantly lower than capdependent first gene expression in a bicistronic vector. Mol Ther 1: 376-382. doi:10.1006/mthe.2000.0050

Mostoslavsky G, Fabian AJ, Rooney S, Alt FW, Mulligan RC. 2006. Complete correction of murine Artemis immunodeficiency by lentiviral vector-mediated gene transfer. Proc Natl Acad Sci 103: 16406-16411. doi:10.1073/pnas.0608130103

Murali A, Rajalingam K. 2014. Small Rho GTPases in the control of cell shape and mobility. Cell Mol Life Sci 71: 1703-1721. doi:10.1007/ s00018-013-1519-6

Murgatroyd C, Wigger A, Frank E, Singewald N, Bunck M, Holsboer F, Landgraf R, Spengler D. 2004. Impaired repression at a vasopressin promoter polymorphism underlies overexpression of vasopres$\sin$ in a rat model of trait anxiety. $J$ Neurosci 24: 7762-7770. doi:10.1523/JNEUROSCI.1614-04.2004
Panda AC, Abdelmohsen K, Yoon JH, Martindale JL, Yang X, Curtis J, Mercken EM, Chenette DM, Zhang Y, Schneider RJ, et al. 2014. RNA-binding protein AUF1 promotes myogenesis by regulating MEF2C expression levels. Mol Cell Biol 34: 3106-3119. doi:10.1128/MCB.00423-14

Pérez-Cañadillas JM. 2006. Grabbing the message: structural basis of mRNA 3'UTR recognition by Hrp1. EMBO J 25: 3167-3178. doi:10.1038/sj.emboj.7601190

Poling BC, Tsai K, Kang D, Ren L, Kennedy EM, Cullen BR. 2017. A lentiviral vector bearing a reverse intron demonstrates superior expression of both proteins and microRNAs. RNA Biol 14: 15701579. doi:10.1080/15476286.2017.1334755

Pont AR, Sadri N, Hsiao SJ, Smith S, Schneider RJ. 2012. mRNA decay factor AUF1 maintains normal aging, telomere maintenance, and suppression of senescence by activation of telomerase transcription. Mol Cell 47: 5-15. doi:10.1016/j.molcel.2012.04.019

Quinn LM. 2017. FUBP/KH domain proteins in transcription: back to the future. Transcription 8: 185-192. doi:10.1080/21541264. 2017.1293595

Raju CS, Göritz C, Nord Y, Hermanson O, López-Iglesias C, Visa N, Castelo-Branco G, Percipalle P. 2008. In cultured oligodendrocytes the A/B-type hnRNP CBF-A accompanies MBP mRNA bound to mRNA trafficking sequences. Mol Biol Cell 19: 3008-3019. doi:10.1091/mbc.e07-10-1083

Raju CS, Fukuda N, López-Iglesias C, Göritz C, Visa N, Percipalle P. 2011. In neurons, activity-dependent association of dendritically transported mRNA transcripts with the transacting factor CBF-A is mediated by A2RE/RTS elements. Mol Biol Cell 22: 18641877. doi:10.1091/mbc.e10-11-0904

Ridley AJ. 2006. Rho GTPases and actin dynamics in membrane protrusions and vesicle trafficking. Trends Cell Biol 16: 522-529. doi:10.1016/j.tcb.2006.08.006

Riquelme PA, Drapeau E, Doetsch F. 2008. Brain micro-ecologies: neural stem cell niches in the adult mammalian brain. Philos Trans R Soc Lond B Biol Sci 363: 123-137. doi:10.1098/rstb. 2006.2016

Rushlow WJ, Rajakumar N, Flumerfelt BA, Naus CC. 1999. Characterization of CArG-binding protein A initially identified by differential display. Neuroscience 94: 637-649. doi:10.1016/ S0306-4522(99)00342-5

Sarig G, Weisman-Shomer P, Fry M. 1997. Telomeric and tetraplex DNA binding properties of qTBP42: a homologue of the CArG box binding protein CBF-A. Biochem Biophys Res Commun 237: 617-623. doi:10.1006/bbrc.1997.7198

Scita G, Nordstrom J, Carbone R, Tenca P, Giardina G, Gutkind S, Bjarnegård M, Betsholtz C, Di Fiore PP. 1999. EPS8 and E3B1 transduce signals from Ras to Rac. Nature 401: 290-293. doi:10.1038/45822

Scita G, Tenca P, Areces LB, Tocchetti A, Frittoli E, Giardina G, Ponzanelli I, Sini P, Innocenti M, Di Fiore PP. 2001. An effector region in Eps8 is responsible for the activation of the Rac-specific GEF activity of Sos-1 and for the proper localization of the Racbased actin-polymerizing machine. J Cell Biol 154: 1031-1044. doi:10.1083/jcb.200103146

Seibenhener ML, Wooten MW. 2012. Isolation and culture of hippocampal neurons from prenatal mice. J Vis Exp e3634. doi: $10.3791 / 3634$

Shaffer SM, Wu MT, Levesque MJ, Raj A. 2013. Turbo FISH: a method for rapid single molecule RNA FISH. PLoS One 8: e75120. doi:10.1371/journal.pone.0075120

Shestakova EA, Singer RH, Condeelis J. 2001. The physiological significance of $\beta$-actin mRNA localization in determining cell polarity and directional motility. Proc Natl Acad Sci 98: 7045-7050. doi:10.1073/pnas.121146098 
Sibilia M, Steinbach JP, Stingl L, Aguzzi A, Wagner EF. 1998. A strainindependent postnatal neurodegeneration in mice lacking the EGF receptor. EMBO J 17: 719-731. doi:10.1093/emboj/ 17.3.719

Sinnamon JR, Waddell CB, Nik S, Chen El, Czaplinski K. 2012. Hnrpab regulates neural development and neuron cell survival after glutamate stimulation. RNA 18: 704-719. doi:10.1261/rna.030742.111

Smidt MP, Russchen B, Snippe L, Wijnholds J, Ab G. 1995. Cloning and characterisation of a nuclear, site specific ssDNA binding protein. Nucleic Acids Res 23: 2389-2395. doi:10.1093/nar/ 23.13.2389

Vaggi F, Disanza A, Milanesi F, Di Fiore PP, Menna E, Matteoli M, Gov NS, Scita G, Ciliberto A. 2011. The Eps8/IRSp53/NASP network differentially controls actin capping and bundling in filopodia formation. PLoS Comput Biol 7: e1002088. doi:10.1371/journal. pcbi.1002088

Wagner B, Natarajan A, Grünaug S, Kroismayr R, Wagner EF, Sibilia M. 2006. Neuronal survival depends on EGFR signaling in cortical but not midbrain astrocytes. EMBO J 25: 752-762. doi:10.1038/sj. emboj.7600988

Walker TL, Kempermann G. 2014. One mouse, two cultures: isolation and culture of adult neural stem cells from the two neurogenic zones of individual mice. J Vis Exp e51225. doi: 10.3791/51225

Wang D, Parrish CR. 1999. A heterogeneous nuclear ribonucleoprotein A/B-related protein binds to single-stranded DNA near the $5^{\prime}$ end or within the genome of feline parvovirus and can modify virus replication. J Virol 73: 7761-7768.

Wang T, Xiao G, Chu Y, Zhang MQ, Corey DR, Xie Y. 2015. Design and bioinformatics analysis of genome-wide CLIP experiments. Nucleic Acids Res 43: 5263-5274. doi:10.1093/nar/gkv439

Wang X, Liu H, Ge H, Ajiro M, Sharma NR, Meyers C, Morozov P, Tuschl T, Klar A, Court D, et al. 2017. Viral DNA replication orientation and hnRNPs regulate transcription of the human papilloma- virus 18 late promoter. MBio 8: e00713-17. doi:10.1128/ mBio.00713-17

Weisman-Shomer P, Cohen E, Fry M. 2002. Distinct domains in the CArG-box binding factor A destabilize tetraplex forms of the fragile X expanded sequence d(CGG)n. Nucleic Acids Res 30: 36723681. doi:10.1093/nar/gkf506

Weiss S, Reynolds BA, Vescovi AL, Morshead C, Craig CG, van der Kooy D. 1996. Is there a neural stem cell in the mammalian forebrain? Trends Neurosci 19: 387-393. doi:10.1016/S0166-2236 (96)10035-7

Wichterle H, Garcia-Verdugo JM, Alvarez-Buylla A. 1997. Direct evidence for homotypic, glia-independent neuronal migration. Neuron 18: 779-791. doi:10.1016/S0896-6273(00)80317-7

Yabuki T, Miyagi S, Ueda H, Saitoh Y, Tsutsumi K. 2001. A novel growth-related nuclear protein binds and inhibits rat aldolase $B$ gene promoter. Gene 264: 123-129. doi:10.1016/S0378-1119 (00)00592-8

Yan CY, Skourides P, Chang C, Brivanlou A. 2009. Samba, a Xenopus hnRNP expressed in neural and neural crest tissues. Dev Dyn 238: 204-209. doi:10.1002/dvdy.21826

Zhang J, Chen QM. 2013. Far upstream element binding protein 1: a commander of transcription, translation and beyond. Oncogene 32: 2907-2916. doi:10.1038/onc.2012.350

Zhang G, Taneja KL, Singer RH, Green MR. 1994. Localization of premRNA splicing in mammalian nuclei. Nature 372: 809-812. doi:10.1038/372809a0

Zhao C, Deng W, Gage FH. 2008. Mechanisms and functional implications of adult neurogenesis. Cell 132: 645-660. doi:10.1016/j. cell.2008.01.033

Zhou ZJ, Dai Z, Zhou SL, Hu ZQ, Chen Q, Zhao YM, Shi YH, Gao Q, Wu WZ, Qiu SJ, et al. 2014. hnRNPAB induces epithelial-mesenchymal transition and promotes metastasis of hepatocellular carcinoma by transcriptionally activating Snail. Cancer Res 74: 2750 2762. doi:10.1158/0008-5472.CAN-13-2509 

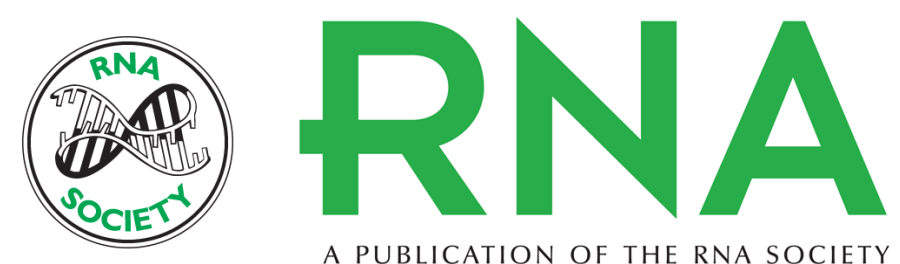

A PUBLICATION OF THE RNA SOCIETY

\section{Hnrnpab regulates neural cell motility through transcription of Eps8}

Alexa A. Lampasona and Kevin Czaplinski

RNA 2019 25: 45-59 originally published online October 12, 2018

Access the most recent version at doi:10.1261/rna.067413.118

Supplemental Material

References

Creative Commons License

Email Alerting Service
http://rnajournal.cshlp.org/content/suppl/2018/10/12/rna.067413.118.DC1

This article cites 100 articles, 31 of which can be accessed free at: http://rnajournal.cshlp.org/content/25/1/45.full.html\#ref-list-1

This article is distributed exclusively by the RNA Society for the first 12 months after the full-issue publication date (see http://rnajournal.cshlp.org/site/misc/terms.xhtml). After 12 months, it is available under a Creative Commons License (Attribution-NonCommercial 4.0 International), as described at http://creativecommons.org/licenses/by-nc/4.0/.

Receive free email alerts when new articles cite this article - sign up in the box at the top right corner of the article or click here.

\section{|||||||| Providing Precise Solutions for} your research.

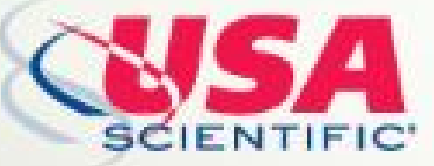

To subscribe to $R N A$ go to:

http://rnajournal.cshlp.org/subscriptions 